DOI 10. 18307/2020. 0511

(C) 2020 by Journal of Lake Sciences

\title{
我国湖泊水文学研究进展与展望”
}

\author{
张 奇**, 刘元波, 姚 静, 赖锡军, 李相虎, 吴桂平, 黄 群, 孙占东, 张 丹, 李云良, 谭志强, \\ 刘星根 \\ (中国科学院南京地理与湖泊研究所中国科学院流域地理学重点实验室,南京 210008)
}

\begin{abstract}
摘 要: 湖泊是地球表层水体的重要组成部分,在区域社会经济发展和生物多样性保护等方面发挥着不可替代的作用. 气候变化和高强度的水资源开发利用等, 导致湖泊物理、化学特性在时空格局上发生显著的变化, 引起一系列的社会、环 境、气候等响应. 湖泊水文学研究湖泊水文要素及其时空变化特征、平衡关系与变化规律,在水文过程演变与归因解析、 湖泊洪旱发生机理与调控、湖泊资源评估与可持续利用等方面, 解决了众多理论和实践问题, 为区域发展提供了强大支 撑. 本文评述了近 50 年来我国湖泊水文学的发展与研究进展, 重点阐述湖泊水量平衡与水量变化、湖泊水动力与水文过 程调蓄、湖泊极端水文事件成因、湖泊水文遥感反演等方面的研究进展,展望了湖泊水文学的未来发展趋势.
\end{abstract}

关键词: 湖泊水文学;湖泊水量平衡;洪涝干旱;湖泊水动力过程;综述

\section{Lake hydrology in China: Advances and prospects*}

ZHANG Qi $^{* *}$, LIU Yuanbo, YAO Jing, LAI Xijun, LI Xianghu, WU Guiping, HUANG Qun, SUN Zhandong, ZHANG Dan, LI Yunliang, TAN Zhiqiang \& LIU Xinggen

(Key Laboratory of Watershed Geographic Sciences, Nanjing Institute of Geography and Limnology, Chinese Academy of Sciences, Nanjing 210008, P.R.China)

Abstract: Lakes are important components of the Earth's surface water bodies. They serve as irreplaceable functions in regional socio-economic development and conservation of biological diversities. Climate variations and intensive water consumption result in significant deviations in temporal change and spatial pattern in terms of physical and chemical processes. As a sub-discipline of hydrology, lake hydrology addresses the changing patterns of hydrological variables, their relationships, balancing and evolution. It addresses fundamental scientific questions and offers solutions to practical issues. Examples includes hydrological attribution and dynamic evolution, hydrological extremes and practical mitigation, lake resources assessment and sustainable utilization, which have been strongly supporting regional developments. This article reviews the progress of lake hydrology in China in the latest 50 years, with emphases on lake water balance and variation, lake hydrodynamics, lake hydrological extremes, and remote sensing of lake hydrology. Several key research areas are also identified and discussed for future research interests.

Keywords: Lake hydrology; lake water balance; flood and drought; lake hydrodynamic process; review

湖泊是陆地表层水体的重要组成. 全球面积大于 $0.1 \mathrm{~km}^{2}$ 的自然湖泊有 142 万个,总面积和总容积分别 为 $2.67 \times 10^{6} \mathrm{~km}^{2}$ 和 $181.9 \times 10^{3} \mathrm{~km}^{3[1]}$. 湖泊是全球尺度水分循环、水量调控和物质能量平衡的重要组成. 我国 湖泊集中分布在长江中下游平原和青藏高原. 我国面积大于 $1 \mathrm{~km}^{2}$ 的天然湖泊 2693 个, 总面积为 81414.6 $\mathrm{km}^{2[2]}$. 在社会经济发展和生物多样性维持等方面起着至关重要的作用.

进人 21 世纪以来,全球湖泊水体的分布格局发生了巨大变化. 全球永久性地表水体在 1984-2015 年间 消失了约 $90000 \mathrm{~km}^{2}$, 同时形成了新的水体 $184000 \mathrm{~km}^{2[3]}$. 我国青藏高原湖泊水位和面积呈加速增长趋

* 2020-07-01 收稿;2020-07-17 收修改稿.

中国科学院南京地理与湖泊研究所重点培育方向 “流域-湖库生态水文过程与模拟” 项目 (NIGLAS2018GH06) 和 国家自然科学基金项目 (41877166) 联合资助.

** 通信作者;E-mail: qzhang@ niglas.ac.cn. 
势 ${ }^{[4]}$; 而长江中下游洪泛平原淡水湖群, 在 2000-2011 年间却呈净减小趋势, 累积减小面积 7.4\% (849 $\left.\mathrm{km}^{2}\right)^{[5]}$, 极端水文事件多发 ${ }^{[6-8]}$. 湖泊面积的扩张或萎缩影响区域水热平衡, 甚至威胁区域水资源安全,并引 起湖泊水环境和水生态的恶化 ${ }^{[9]}$, 给社会经济的可持续发展带来极大挑战. 在极端气候条件和强人类活动 影响下, 湖泊水文过程演变出现了新的特征, 赋予了湖泊水文学新的研究内容, 对研究方法和研究手段提出 了新的要求. 本文系统梳理总结湖泊水文学的研究进展, 阐述近 50 年来我国湖泊水文学的研究进展, 指出 湖泊水文研究难点和未来发展趋势, 为水文学和湖沼学等相关学科的发展提供参考借鉴.

\section{1 湖泊水文学的发展及重要进展}

我国古籍《行水金鉴》记载了湖泊水文的早期研究. 这是一部综合性水利书籍, 清雍正三年 (1725 年) 成 书. 书中涉及湖泊面积、河湖关系、湖泊水位涨落、湖泊变迁等内容. 我国湖泊的水文观测大多始于 $1920 \mathrm{~s}$, 比 如, 太湖、洞庭湖和鄱阳湖等湖泊的水文观测. 新中国成立后, 湖泊水文研究蓬勃发展, 先后进行了多次全国 湖泊调查, 获得了全国湖泊数量及面积等基础数据系列, 建立了湖泊水文基础数据库, 支撑了湖泊水文学 研究 ${ }^{[10]}$.

我国著名水文学家施成熙先生定义湖泊水文学为“以湖水为研究对象, 研究湖水的来源与去路、湖水的 理化性质及湖水中各种水文现象的发生、发展过程及其内在联系, 以及湖泊资源的控制和利用的学科” ${ }^{[11]}$. 依据研究对象和内容, 湖泊水文学是水文学 (hydrology) 的一个分支. 目前国际上尚没有专门的英文词汇, 通 常用 limnology (湖沼学) 来表达. 湖沼学的研究对象是内陆水体, 其研究内容更为宽泛, 除了水的物理过程, 还包括化学、生物等过程 ${ }^{[12]}$.

湖泊水文学是研究湖泊水量变化和湖水运动的一门学科. 湖泊水文要素及湖泊水量平衡关系的变化是 湖泊水文学的核心内容, 包括水量平衡关系的建立、湖泊水量变化的影响因素以及湖泊水量对气候变化的 响应等. 作为湖泊水量变化的一种极值状态, 湖泊洪水和干旱等极端水文过程对生态系统和社会经济等影 响巨大, 其过程演变及归因分析可为防洪抗旱等提供科学依据, 是湖泊水文学所必须面临的基本现实问题. 湖泊水动力过程主导着湖泊物质的迁移转化、温度等物理属性的时空分布, 影响湖盆冲淤及洲滩发育以及 湖泊演化和湖泊功能, 是湖泊水文学的重要组成内容. 随着空间观测技术的快速发展, 湖泊水文遥感在湖泊 水文过程研究中发挥了不可替代的作用, 成为湖泊水文学重要的研究手段. 湖泊水文学还涉及泥沙动力过 程、热力过程、污染过程和生态过程等内容, 本文不做重点阐述.

\section{1 湖泊水量平衡与湖泊水量变化}

湖泊水量取决于来水量和排水量之间的动态平衡关系, 湖泊水量的变化影响着湖泊水资源安全和湖泊 生态系统健康与服务. 受全球气候变化和人类活动的影响, 湖泊水量时空格局正发生着巨大的变化. 研究湖 泊水量平衡是评估全球变化下地球表层水量变化的重要组成内容,是应对气候变化、保障区域水量安全、维 持湖泊正常功能的核心研究内容.

1.1.1 湖泊水量平衡湖泊水量平衡指以湖泊水体为对象, 在某时段内, 湖泊水量的增量等于所有进人湖泊 的水量减去所有排出湖泊的水量. 进入湖泊的水量一般包括流域人湖地表径流 $\left(S_{1}\right)$ 、大气降水 $(P)$ 、地下水 补给 $\left(G_{1}\right)$ 等, 出湖水量一般包括河道排泄 $\left(S_{0}\right)$ 、水面蒸发 $(E)$ 、地下水渗漏 $\left(G_{0}\right)$ 、人为取水 $(W)$ 等 $($ 图 1$)$. 湖 泊水量平衡研究即计算某时段内湖泊水量的变幅,分析变化的原因.

在计算湖泊水量平衡时, 常常采用湖泊库容曲线方法. 依据湖泊水位, 由库容曲线即可计算出对应的湖 泊水量. 湖泊库容曲线的建立依赖于实测的湖泊水位, 结合湖盆地形计算相应水面面积和蓄水量, 表达为数 学公式或直接用数据点绘制而成 ${ }^{[13]}$. 库容曲线的形态受湖盆地形地貌和湖泊与上下游水系的水力联系影 响, 可能呈现一定的非线性特征. 该非线性特征意味着湖泊水位上升和下降过程对应的湖泊面积和蓄水量 变化路径是不同的,上升曲线和下降曲线形成环状的圈, 同一个湖泊水位值在不同的阶段对应不同的湖泊 面积和水量, 这种现象称为迟滞效应, 也称绳套, 常见于大型的洪泛型浅水湖泊 ${ }^{[14]}$. 湖泊水位一水量关系的 迟滞效应从本构关系上表征了湖泊水文的非线性特征, 在湖泊水文节律演变规律的揭示和湖泊水文模拟方 面提供了物理依据 ${ }^{[15-17]}$.

湖泊水量平衡关系不仅影响湖泊的储蓄水量, 还影响湖泊的演化和功能发挥 ${ }^{[1-20]}$. 不同气候区湖泊水 


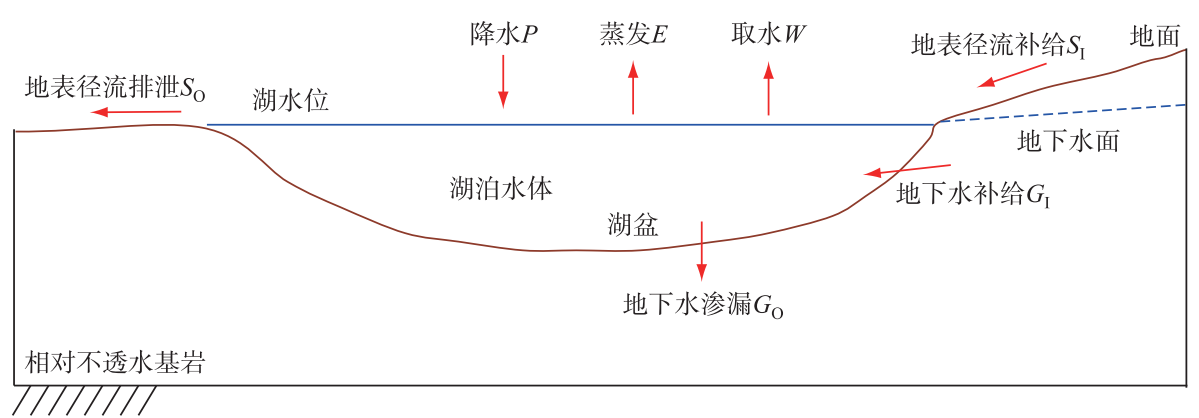

图 1 出人湖泊的水组分示意图

Fig. 1 Inflows and outflows of lake water balance components

量平衡的关键影响因子不尽相同 ${ }^{[18]}$. 在干旱和半干旱区, 降水和蒸发是湖泊水平衡的关键影响因素. 以博 斯腾湖为例, 湖泊水量呈现显著的阶段性特征, 主要原因是流域降水发生变化引起人湖水量的阶段性偏少 或偏多 ${ }^{[17,21-22]}$. 由于蒸发量巨大, 干旱、半干旱区湖泊在降水不足的情况下, 往往会损失巨大蓄水量, 使水体 盐分含量逐渐增大, 甚至最终演化成盐湖. 我国的盐湖主要分布在青海、新疆、西藏及内蒙古等地区 ${ }^{[10]}$. 在 湿润区和半湿润区, 湖区降雨和蒸发基本均衡, 流域人湖径流和湖泊向水系排泄是控制湖泊水量平衡的直 接因素. 比如, 北美五大湖的年蒸发量与人工取水量之和与湖面降水量基本持平, 五大湖的径流量主要来自 流域降雨径流和春季融雪补给, 湖泊水量的年内变化显著 ${ }^{[23-24]}$. 对洪泛平原湖泊来说, 面积巨大的洪泛区往 往对湖泊的水量平衡起着重要的作用. 代表性工作包括塔纳湖 (Lake Tana) 水量平衡的研究 ${ }^{[25]}$ 和洞里萨湖 (Tonle Sap Lake) 的水量平衡分析 ${ }^{[26]}$. 两个湖泊都有巨大的洪泛区域, 洪泛区域在湖泊水量平衡中作用明 显. 塔纳湖的水量平衡关系中有 $6 \%$ 的河流入湖径流在流经洪泛区时损失, 而洞里萨湖与涺公河 ( Mekong River) 发生显著的水量交换, 其年人湖水量中高达 $50 \%$ 以上来自湄公河干流. 类似的工作还包括长江中游洪 泛湖泊鄱阳湖的水量变化研究, 在丰水期 6-8 月份, 洪泛区的水量调蓄作用明显, 洪泛区蓄水量占 $57 \%$, 超 过了永久湖盆水道 (一年四季都淹没的区域) 的蓄水量 $(43 \%)^{[14]}$. 平原洪泛湖泊的另一个特点是发育着众 多的子湖, 当主湖水位下降后, 这些子湖就出露形成互相独立的小水体. 有研究表明, 面积大于 $1 \mathrm{~km}^{2}$ 的 77 个子湖在低水位时期占全湖水量的 $5.6 \%$, 但面积比例达 $18.5 \%{ }^{[27]}$. 相对于干旱区湖泊, 湿润区洪泛湖泊与 周围水系水力连通良好, 排水条件通畅, 换水周期短, 污染物不易累积, 但水沙平衡的变化往往造成湖盆和 洲滩的发育或退化, 影响湖泊生态功能 ${ }^{[6,10]}$.

在湖泊水量平衡中, 地下水的补排量较难确定. 目前常运用地下水模型, 结合地下水观测数据进行计 算,但带有较大的不确定性. 也可以采用同位素技术分辨地下水组分, 特别是在干旱、半干旱区 ${ }^{[28-29]}$ 应用广 泛, 比如, 羊卓雍错的渗漏量计算 ${ }^{[30]}$ 、岱海和乌梁素海的地下水补给计算 ${ }^{[31]}$ 等. 在长江中下游湿润区, 大型 浅水湖泊与洪泛区地下水存在强水力联系, 地下水位对湖泊水位变化的响应显著, 水量交换明显 ${ }^{[32-33]}$. 由于 水系、地形、地貌、土壤的高度空间异质性, 地表、地下水体之间的水文连通时空变化复杂 ${ }^{[19,34-35]}$, 水交换量的 确定尚存在一定的难度. 同位素技术联合地表一地下水模型或将是有效的研究手段,但相关研究尚缺乏.

1.1.2 湖泊水量变化及驱动因素 湖泊水量呈动态的平衡状态, 当这种平衡被严重打破时, 湖泊水量将呈现 持续性减少或增加的趋势. 近 20 多年来, 湖泊水量的变化尤为显著, 其原因大多为气候变化的影响, 其次是 水利工程引起的河湖水系结构的调整导致河湖水文关系的改变,继而影响湖泊出人水平衡关系 ${ }^{[36-39]}$.

研究湖泊水量变化需要考虑流域及周边相连的水系, 常常借助数学模型解析湖泊水量变化的影响因 素, 预测其未来的变化趋势. 视不同时间尺度的需要, 湖泊水位和水量的模拟可以是基于经验回归模型的月 或年尺度, 比如, 湖泊月水位与流域气温和流域径流量的回归模型 ${ }^{[36]}$, 也可以是基于日尺度的统计和机器学 习模型 ${ }^{[40]}$ 或具有全物理机理的水动力模型 ${ }^{[41]}$. 这些模型以湖泊为模拟对象, 以流域气象水文条件和湖泊出 口的水文条件作为模型输人项,计算湖泊水量的变化. 也有研究将湖泊及其集水域作为完整的研究区, 把湖 泊作为研究区的内部水体, 通过流域水文模型和湖泊水文模型的堣合, 计算湖泊水量对流域气候变化和覆 
被变化的响应. 这类模型的优势是将流域与湖泊进行了耦合, 湖泊水量与流域地下水实现了双向的耦合反 馈, 更为真实地模拟湖泊与地下水含水层之间的水量交换以及湖区的产汇流过程 ${ }^{[42-43]}$. 表 1 列举了基于水 量平衡方程、统计学、机器学习和水动力方程 4 种不同原理和方法的湖泊水文模型, 这些模型针对不同类型 湖泊及模拟目的,开展了成功的应用研究.

表 1 几种代表性湖泊水文模型

Tab.1 List of representative types of lake hydrology model

\begin{tabular}{|c|c|c|c|}
\hline 类型 & 模型名称或原理 & 应用案例 & 文献 \\
\hline I & $\begin{array}{l}H=\mathrm{f}(T, R)(\text { 统计回归 }) \\
\text { 变量: 水位 } H(\mathrm{~m}) \text { 、气温 } T\left({ }^{\circ} \mathrm{C}\right) 、 \text { 人湖径流量 } R\left(\mathrm{~m}^{3}\right) \\
\text { 尺度:月 }\end{array}$ & $\begin{array}{l}\text { 鄱阳湖; } \\
\text { 相关系数 } 0.80\end{array}$ & {$[36]$} \\
\hline II & $\begin{array}{l}\text { 神经网络模型 }(\text { BPNN })(\text { 机器学习 }) \\
\text { 变量: 人湖流量 }\left(\mathrm{m}^{3}\right) \text { 、水位 }(\mathrm{m}) 、 \text { 湖泊水位 }(\mathrm{m}) \\
\text { 尺度:日 }\end{array}$ & $\begin{array}{l}\text { 鄱阳湖; } \\
\text { 相关系数和纳西效率系数均大于 } \\
0.90\end{array}$ & {$[40]$} \\
\hline III & $\begin{array}{l}\text { 水量平衡模型(出人湖水量之差等于湖泊水量增量) } \\
\text { 变量: 河流入湖水量、湖面降水量、农田排水人湖水 } \\
\text { 量、坡面人流、地下水人渗量、地下水出渗量 } \\
\text { 时间尺度:年际、日 }\end{array}$ & $\begin{array}{l}\text { 博斯腾湖、洞里萨湖 ( Tonle Sap } \\
\text { Lake) }\end{array}$ & {$[21,26]$} \\
\hline $\mathrm{IV}$ & $\begin{array}{l}\text { 水动力模型 }(\text { 全物理机制水力学方程 }) \\
\text { MIKE21、POM、CANDIE、ELCOM } \\
\text { 变量:气温、风速、人湖水量、出湖水量或水位 } \\
\text { 尺度: 日或以下 }\end{array}$ & $\begin{array}{l}\text { 鄱阳湖、安大略湖; } \\
\text { 纳西系数大于 } 0.90 \text {, 均方根差为 } \\
0.85 \sim 1.73^{\circ} \mathrm{C}\end{array}$ & {$[14,41]$} \\
\hline
\end{tabular}

气候变化对湖泊水量的影响通常联合气候模式和湖泊水文模型加以预测. 这方面的工作已有很多的报 道. 比如, 未来不同温室气体排放对北美五大湖地区的影响, 相对于低温室气体排放, 高温室气体排放将引 起蒸散发的高增加. 在高温室气体排放情景下, 随着气温的总体增加, 冰盖将逐渐消退, 总体上湖泊的水位 将下降 ${ }^{[4]}$. 而亚热带季风区的长江中下游湖泊, 未来气候变化可能导致降雨年内分异更为明显, 湖泊水量 将呈现枯水季更旱、丰水期更洪的两极分化,湖泊洪水和干旱程度有进一步加剧的风险 ${ }^{[36,45]}$. 在湖泊水量变 化的预测中, 常带有较大的不确定性. 该不确定性来自于气候模式和水文模型, 且气候模式输出结果的偏差 有可能在水文模型中被进一步放大. 目前常采用集合化模拟以减小预测结果的不确定性. 比如, 采用了 7 个 全球影响模型 (global impact models, GIMs) 开展气候变化对干旱的集合化模拟, 而驱动这些 GIMs 的气候变 化情景又来自 5 个全球气候模型 (global climate models, GCMs), 在某种程度上可减小输出结果的不确定性, 提高预测结果的可信度 ${ }^{[46]}$.

\section{2 湖泊极端水文事件}

在全球变化影响下, 热浪和暴雨愈发严重, 导致湖泊水量发生显著变异, 湖泊干旱、洪水等极端水文事 件发生频次增大, 强度也有所增强, 严重威胁湖区和岸线的生命财产安全, 并给水生生态系统带来了颠覆性 影响 ${ }^{[47-51]}$. 以 2017 年洞庭湖特大洪水为例, 湘江、资水、沅水 3 条干流及洞庭湖区共 24 站点水位超警戒值, 直接经济损失达 60.14 亿元 ${ }^{[22-53]} .2020$ 年 7 月长江中下游降雨持续增多, 鄱阳湖水位快速上涨, 至 2020 年 7 月 13 日 5:00,星子站水位达 $22.60 \mathrm{~m}$, 超警戒水位 $3.6 \mathrm{~m}$, 刷新历史最高水位 $(22.52 \mathrm{~m}$ ) (江西省水利厅实时 共享数据). 但同时, 洞庭湖、鄱阳湖干旱加剧, 秋、冬季枯水期水位也创历史新低 ${ }^{[6,20,39]}$. 研究气候变化叠加 人类活动影响下的湖泊极端水文过程发生机理, 是湖泊水文学的重要内容, 也是当前水文水资源研究领域 的热点问题之一, 对湖泊防洪抗旱减灾以及应对全球变化具有现实意义.

1.2.1 湖泊极端水文事件及其识别方法 湖泊极端水文事件指在特定时间尺度上湖泊水文过程发生的小概 率事件,一般具有相对的水文极值、持续的时间、对湖泊水安全和水生态环境产生严重影响等特征 ${ }^{[54-56]}$. 研 究湖泊极端水文事件最常用的水文变量是湖泊降水和水位, 这些变量相对易于获取且时间序列较长, 对湖 泊水文特征的描述也最为直观 ${ }^{[57-59]}$. 随着模型模拟技术的发展, 湖泊水面积、蓄水量、流速、洲滩湿地的淹没 
面积等变量也逐渐被用来研究湖泊极端水文事件, 这对于进一步探索极端水文事件对湿地生态水文过程、 湖泊水生态系统和水环境的影响具有重要意义 ${ }^{[15,32,60]}$.

目前, 湖泊极端水文事件的识别并没有统一的标准, 而湖泊水文极值的确定是湖泊极端水文事件识别 的关键内容. 湖泊水文极值的确定方法主要包括 3 种: (1) 经验法. 根据水位等湖泊水文变量对当地生产和 生活产生的影响来确定 ${ }^{[61-63]}$. 以鄱阳湖为例, 认为当都昌站水位低于 $14 \mathrm{~m}$ 时湖泊进人了枯水状态, 当星子 站水位高于 $19 \mathrm{~m}$ 时则认为湖泊发生了洪水事件 ${ }^{[2-63]} ;$; 2) 极值法. 特定时间段内湖泊水文变量的最大/小 值 ${ }^{[64-66]}$. 如 1998 年鄱阳湖洪水事件中, 湖口站和星子站分别出现了历史最高水位 22.59 和 $22.52 \mathrm{~m}$; (3) 极值 分布函数,包括广义极值分布函数、皮尔逊 III 型函数、韦布函数等 ${ }^{[67-68]}$; (4) 标准化湖泊水位法. 运用伽马函 数和标准化方法, 将湖泊水位转换为正态分布, 利用概率值确定干旱强度, 并可确定干旱事件的起止时间和 干旱程度等 ${ }^{[69]}$. 比如, 基于广义极值分布函数发现 2011 年是鄱阳湖 1960- 2013 年最为干旱的年份 ${ }^{[70]}$. 根 据研究的区域和时间尺度, 不同学者选择不同的湖泊水文变量和水文极值确定方法来识别相应的湖泊极端 水文事件,进而对湖泊极端水文事件的基本特征进行分析, 主要包括: 极端事件的起止时间、持续时间、严重 程度、峰值、发生频率、幅度、变化趋势等, 这些是湖泊极端水文事件研究中讨论最为广泛的内 容 ${ }^{[20,54,60,68,70-73]}$. 基于实测流量数据, 研究了长江上游与洞庭湖洪水遭遇频率、遭遇程度、持续时间等方面的 特征, 结果表明该地区洪水发生频繁, 发生时段主要集中在 6-7 月 ${ }^{[74]}$; 基于年最大洪峰流量和年最高洪水 位数据, 分析了洞庭湖三口水文极值的变异特性, 发现年最大洪峰流量和年最高洪水位具有向下突变的 趋势 ${ }^{[75]}$.

1.2.2 湖泊极端水文事件成因及归因方法 湖泊极端水文事件的产生是流域出、人湖水文过程和湖泊自身水 量收支过程共同作用的结果 ${ }^{[76-79]}$. 流域水文过程受气候、土地利用/覆被变化和社会经济发展用水的综合影 响, 湖泊本身作为陆一气交互作用的特殊界面, 降水、蒸发等水热条件剧烈波动, 加之湖区围脣养殖、湖泊水 沙开采、水利工程建设等人类活动的影响, 使湖泊极端水文事件的成因异常复杂. 常用的成因识别方法可分 为统计分析法和数值模拟法, 其中, 统计分析法主要用于湖泊极端水文事件成因的定性识别, 包括相关分析 法和联合分布函数法 ${ }^{[70,80-84]}$; 数据模拟法主要用于湖泊极端水文事件成因的定量识别, 包括机器学习法和水 文水动力方法 ${ }^{[20,73,85-87]}$. 此外, 基准期, 即未发生极端水文事件时期的选定是研究湖泊极端水文事件成因的 前提, 直接影响到归因结果. 基准期的选定有两种: 一是选择没有发生湖泊极端水文事件的历史时期; 二是 模拟没有发生湖泊极端水文事件时的假定情景.

流域来水和湖泊本身的降水和蒸发水量收支作为极端水文事件产生的水分来源, 是影响湖泊极端水文 事件的关键因素. 就湖泊洪水事件而言, 其发生的主导因素一般是气象条件, 即发生了极端来水或湖泊本身 发生了极端降水事件 ${ }^{[22,88-91]}$. 2016-2017 年青藏高原中部湖泊水位的剧烈波动是由厄尔尼诺引起的降水变 化导致的 ${ }^{[54]}$; 而 2017 年洞庭湖特大洪水是由流域极端来水和湖区极端降水共同引起的 ${ }^{[52]}$. 对于长江中游 的大型通江湖泊而言, 湖泊洪水过程的形成与流域洪峰过程和长江洪峰过程的遭遇时间相关, 长江洪峰的 错峰可有效降低湖泊洪水发生的风险 ${ }^{[22-93]}$. 相对而言, 湖泊干旱事件的成因比较复杂. 这是因为湖泊干旱事 件涉及的各因素间有着强烈的陆一气交互作用, 且干旱事件的持续时间较长、影响范围较广, 加之湖泊类型、 所处气候区和研究尺度的差异, 不同的研究得出的湖泊干旱事件的主导因素有所差异. 主要包括: (1)气象 条件为主导. 降水、冰雪融水等气象条件引起的流域来水减少、湖泊降水减少和蒸发增加, 是湖泊干旱发生 的触发器, 这种类型的湖泊干旱事件可发生于全球所有气候类型的湖泊 ${ }^{[84,94]}$. 比如, 美国中部平原地区小 型湖泊的干旱事件主要受到冰雪融水引起的人湖径流减少和蒸发增加的影响 ${ }^{[94]}$; 而流域降水减少引起的人 湖径流降低是 1963 年鄱阳湖春季干旱发生的主要原因 ${ }^{[95]}$; (2) 高湖泊资源开发强度为主导. 下垫面改变、 湖区围垦、人类取用水和水库调蓄等人类活动一方面影响人湖径流量, 另一方面直接影响湖泊的容积蓄水 量, 这种类型的湖泊干旱事件主要发生在水资源比较匮乏、人类开发利用湖泊资源强度较高的干旱半干旱 区湖泊. 比如, 人类活动引起的人湖径流量减少是白洋淀发生干旱的主要原因 ${ }^{[96]}$; 人类活动对 $1999-2010$ 年伊郎西部的乌尔米亚湖干旱事件的贡献量高达 $72 \% \sim 87 \%{ }^{[78]}$; (3) 江湖关系改变为主导. 对于过水型湖泊 和吞吐型湖泊而言, 除了人湖水文过程、湖泊降水和蒸发影响外, 湖泊出流过程改变也是影响极端水文事件 的重要因素 ${ }^{[63,80,92,95]}$. 比如, 长江中下游通江湖泊的干旱趋势除了气候变化大背景外, 长江上游大型水库 
运行造成的下游径流减少、干流河床持续冲刷下切而引起的江湖关系调整, 是导致湖泊秋、冬蓄水量显著减 少的主导因素 $[38,77,95]$.

\section{3 湖泊水动力与调蓄过程}

湖泊水动力与调蓄过程是湖泊生态系统的基本过程. 湖泊水动力驱动湖泊泥沙和营养物质的输移和扩 散,改变湖泊生态系统的物理环境条件,进而影响湖泊化学元素的循环和生物栖息地条件,同时也影响着能 量的传输, 是决定湖泊生态系统结构功能的基础. 湖泊调蓄流域来水、改变来水水动力特性, 对湖泊环境和 生态有重要影响. 湖泊水动力研究既涉及以深水湖泊密度分层为主的动力特性研究, 也涉及以浅水湖泊为 代表的风生流、吞吐流研究. 研究尺度既有微观的紊动水流结构特征探究 ${ }^{[97]}$, 又有以宏观环流运动特征为 主的解析 ${ }^{[98]}$.

1.3.1 湖泊水动力过程 观测和模拟是湖泊水动力过程研究的主要手段. 水动力现场观测早期手段较为缺 乏, 主要是单点的流速调查. 我国最早于 $1960 \mathrm{~s}$ 就开展了太湖等大型湖泊的湖流和波浪等调查 ${ }^{[99]}$, 为湖泊研 究提供了重要的基础数据 ${ }^{[100]}$. $1970 \mathrm{~s}$ 以来, 采用数学模型模拟河湖水动力得到快速发展, 并在湖泊水动力研 究中得到应用. 在 $1990 \mathrm{~s}$ 建立了太湖、滇池、洪泽湖等湖泊的水动力模型, 开展了湖泊环流结构、内波等的研 究,为深化认识湖泊水动力过程奠定了基础. 近年来, 随着高分辨率高频的三维垂线流速测试、走航式三维 流速测试、平面大范围流场测试等手段的发展, 湖泊水动力原位观测能力得到快速发展, 显著提升了湖泊水 动力过程机理的研究水平 ${ }^{[101]}$. 而数学模型可经济、快速地获取时间和空间上完整的湖泊水动力过程, 成为 研究大尺度湖泊水动力过程不可或缺的手段,在科研和工程实践中得到广泛应用 ${ }^{[102-105]}$.

浅水湖泊湖流主要可以分为风生流和吞吐流, 以风生流为主. 太湖是我国典型的风生流浅水湖泊,表现 为表层风生流及底部反向补偿流构成的垂向二维环流模式 ${ }^{[98,106]}$; 太湖不同季节及典型风场下的环流形式 不尽相同 ${ }^{[98,107-108]}$; 水动力过程的模拟在刻画太湖风涌水特征 ${ }^{[109-110]}$, 揭示地形变化的影响 ${ }^{[111]}$ 、典型台风对 水动力场的影响 ${ }^{[112]}$ 、围垦的影响 ${ }^{[108]}$ 等方面成果斐然. 同时, 太湖也是水环境和水生态问题最为突出和典型 的湖泊之一, 水环境和水生态问题成为近 20 年来湖泊水文学研究的内容之一. 为此, 研发了耦合湖泊水动 力水质和生态的模型, 在研究太湖营养盐、透明度的时空异质特点及影响因素 ${ }^{[11-116]}$, 定量评估调水工程对 水动力及水环境改善效果 ${ }^{[117-118]}$, 预报藻源性湖泛和蓝藻水华暴发 ${ }^{[119-121]}$ 等方面都取得了新的进展.

通江湖泊由于受流域和江河影响, 水动力以重力型吞吐流为主, 且存在季节性变化特征. 洞庭湖和鄱阳 湖受流域和长江的双重影响, 水位变幅巨大, 水动力存在显著的时空异质性特点, 对江湖关系变化、气候变 化和人类活动极为敏感. 研发了长江中游江湖河一体化的一 二维耦合水动力数学模型 ${ }^{[122]}$, 并构建了洞庭 湖 ${ }^{[123]}$ 和鄱阳湖 ${ }^{[73,124-125]}$ 水动力模型. 模型充分采用干湿判别法处理频繁的露滩和淹没过程, 采用局部加密 技术,较为理想地刻画了通江湖泊 “洪水一面、枯水一线” 的特点. 在模拟水位、淹水面积和流场变化及其对 江湖关系的定量化响应方面, 取得了显著进展. 基于水动力模拟, 获取了鄱阳湖水位对流域来水和长江来水 的定量响应特征 ${ }^{[126]}$, 量化了三峡水库运行对湖泊水位、流量的影响 ${ }^{[127]}$. 针对近年来极端低水事件, 从水动 力角度量化了流域和长江来水对低水的贡献权重, 得到了春季低水主要由流域引起、秋季低水则多为长江 主控的结论. 此外, 采砂引起的人江通道地形下切对水位的影响亦不可忽视, 采砂引起鄱阳湖枯季泄洪能力 增加 $1.5 \sim 2$ 倍 ${ }^{[128]}$, 北部人江通道水位下降 $1.2 \sim 2 \mathrm{~m}^{[129-130]}$. 通江湖泊水动力并非只呈现单一的吞吐流态, 特 定条件下, 还存在倒灌流和风生流. 基于鄱阳湖水动力模型, 刻画了特定江湖关系下出现的倒灌流特征, 最 大倒灌距离可达到上游的康山 ${ }^{[93]}$; 识别了鄱阳湖风控区为东部湖湾和西部近岸区 ${ }^{[131]}$; 同时也发现, 虽然鄱 阳湖整体上呈二维流态, 但湖区中部及东部在夏季存在垂向温度分层现象 ${ }^{[132]}$. 再者, 湖泊水动力模拟在定 量评估鄱阳湖拟建水利枢纽工程的影响 ${ }^{[133-134]}$, 刻画鄱阳湖水动力、水质和悬沙场的时空异质性方面 ${ }^{[135-139]}$, 也发挥了重要作用.

深水湖泊往往存在垂向分层现象. 不同湖区表、中、底层呈现不同形式的水平及垂向环流结构. 太阳辐 射对湖水表层的加热使得表、底层产生温度差异, 导致水体密度分层. 这种垂向结构受季节变化影响,冬季 相对混合较好, 而夏季则明显分层 ${ }^{[140]}$. 因而, 深水湖泊大多采用三维模型, 如北美五大湖区 ${ }^{[41,105,141]}$ 、非洲 大湖区 ${ }^{[142] 、 贝 \text { 、加尔湖 }}{ }^{[143]}$ 、抚仙湖 ${ }^{[144]}$ 等深水湖泊的模拟. 模拟要素涉及温度、密度、压力等的时空变化,空间 环流结构和温跃层生成及变化形式等. 
1.3.2 湖泊调蓄过程 湖泊调蓄在缓解洪涝与维系湖泊湿地生态功能方面发挥着重要作用 ${ }^{[127-128]}$. 湖泊自身 的容积、面积和形态是决定其调蓄功能的基本条件 ${ }^{[129]}$, 河湖关系则改变了湖泊的调蓄性能 ${ }^{[93,130]}$, 气候变 化、土地利用和水利工程运行间接地影响了湖泊的调蓄作用 ${ }^{[131]}$. 季节性的河湖相互作用对湖泊调蓄性能的 改变很大程度上可以影响到湖泊的环境质量 ${ }^{[145]}$, 而外部环境的变化对湖泊调蓄功能具有一定的累加效 应 ${ }^{[134-135,146]}$. 长江中游地区大型吞吐湖泊受江湖关系影响, 其调蓄功能与作用备受关注 ${ }^{[136-139]}$. 这些通江湖 泊调蓄容量大, 对长江中游的防洪有着举足轻重的作用. 洞庭湖多年平均削峰量达 $30 \% .1954$ 年特大洪水 期间, 削减洪峰流量 $27400 \mathrm{~m}^{3} / \mathrm{s}$, 占洪峰量的 $40 \%$, 极大地减轻了长江干流的洪水压力 ${ }^{[139]}$. 1950s 以来, 随着 大规模的围怎活动和快速泥沙淤积, 湖泊调蓄容积急剧减少, 1990s “小水大灾” 现象频现 ${ }^{[147]}$. 这些变化推动 了长江中游湖泊调蓄功能研究的发展, 从不同角度探讨了湖泊容积减少与湖泊调蓄能力降低的关系. 研究 表明, 洞庭湖的调蓄总量和滞时作用与不同时间尺度的洪水波有关, 削减的洪峰主要是月中短尺度洪水波, 削峰系数在 $0.13 \sim 0.56$ 之间 ${ }^{[139]}$. 洞庭湖削峰系数与城陵矶一螺山水位落差的多年变化过程呈反向特征, 表 明洞庭湖的调蓄功能很大程度上也受控于湖泊出口之下长江的过水能力. 阻流型堤垸对局部区域水情影响 较大, 而调蓄型堤垸对水情影响较小 ${ }^{[148]}$. 长江上游三峡水利工程的运行有效地削减了长江主汛期干流的洪 峰,缓解了长江中游的洪水压力, 间接地降低了中游洞庭湖和鄱阳湖对洪水的调蓄作用 ${ }^{[149]}$.

\section{4 湖泊水文遥感}

湖泊面积、水位和蓄水量等物理参数, 是表征湖泊受气候变化与人类活动影响程度的重要指示 器 ${ }^{[150-151]}$. 随着全球范围内湖泊流域水资源与环境问题日益受到重视, 实时、准确地监测湖泊水情要素及其 变化, 对于湖泊水文过程的研究、水资源优化调控以及生态环境建设等均具有十分重要的意义 ${ }^{[152]}$. 近几十 年来, 随着空间观测技术的快速发展, 不同时空分辨率的光学、微波和雷达等多源遥感数据的相继出现, 给 湖泊水情研究打开了一扇信息大门 ${ }^{[153-155]}$. 遥感技术具有宏观性、动态性和实时性的优势, 可以实现不同空 间范围湖泊水体的动态监测, 极大地弥补了传统地面观测系统的不足, 在揭示湖泊过程空间变化上带来了 新的科学认知, 成为湖泊水情监测和水资源调查不可替代的先进手段.

1.4.1 湖泊水文遥感技术方法 遥感技术应用于湖泊水情的监测研究, 可追溯至 $1970 \mathrm{~s}^{[156]}$. 遥感技术发展之 初, 国内外研究者主要依靠可见光/近红外波段实现湖泊水情的监测 ${ }^{[157]}$. 随着卫星技术的不断发展, 不同时 空分辨率的红外、微波、雷达等传感器相继出现, 为湖泊水情监测提供了越来越多的技术手段. 由于传感器 响应电磁波段特性的差异, 不同技术手段的湖泊水情探测能力也大不相同: 可见光一近红外数据由于具有时 空分辨率高、成本低等特点, 已被广泛应用于中小尺度湖泊的水体监测中, 但是其往往难以捕捉云雨天气下 的湖泊水情信息 ${ }^{[153,158]}$; 被动微波亮温数据的获取不受天气条件的限制, 而且重访周期高, 较适合于全天候 湖泊水体的识别和监测 ${ }^{[159]}$, 但是其空间分辨率较低 (数十千米), 更多的只能应用于诸如亚马逊河流域、长 江流域等较大区域范围的水体监测中 ${ }^{[160]}$, 在内陆湖泊的应用中受到一定限制; 合成孔径雷达 (SAR) 具有穿 透云雾、湿地挺水植被及洪溢林等特性, 成为监测湖泊水体的重要手段, 但是 SAR 数据费用较高, 而且受到 相干斑点噪声的影响, 往往限制了其应用的范围 ${ }^{[157,161]}$. 针对单一传感器在时空连续性和提取精度等方面的 局限性,近年来运用多传感器联合的手段来监测湖泊水面变化逐渐被相关研究者采 用 $^{[162-163]}$. 研究表明, 基 于多传感器联合的手段可以充分实现不同遥感数据之间的优势互补, 能够在一定程度上有效提高湖泊水情 获取的时空精度 ${ }^{[164-165]}$.

利用遥感数据开展湖泊水情监测的方法很多. 根据时间发展的先后顺序以及目标对象的不同, 总体上 可以分为单波段法、多波段法以及多波段融合等方法 ${ }^{[158]}$. 针对湖泊水面信息,先后出现了诸如单波段法、光 谱波段指数法、分类法和密度分割法等多种水体提取方法 ${ }^{[16-168]}$. 研究表明, 通过构造光谱波段指数 (如 NDVI、NDWI 等) 配合确定的最优阈值来提取水面信息, 是目前光学遥感最有效的方法之一 ${ }^{[153,169]}$; 湖泊水位 信息的获取主要有水位一面积关系法和 DEM 叠合法两种方法 ${ }^{[170]}$, 但是这两种方法由于受下垫面条件差异 的限制以及湖盆 DEM 的依赖性, 适用性欠佳 ${ }^{[157]}$. 随着微波遥感和雷达高度计等数据逐渐应用到湖泊水情 监测, 产生了聚类分析法、极化比值法、面向对象法、多时相变化检测法 ${ }^{[160,171-173]}$ 等多种水面信息遥感提取方 法. 涉及湖泊水位信息遥感提取的高度计数据遴选、波形分类、波形重跟踪等数据处理方法也应运而 生 ${ }^{[155,165,174-177]}$. 鉴于不同卫星传感器数据的差异性,协同发展适用于湖泊水情信息提取和监测的数据融 


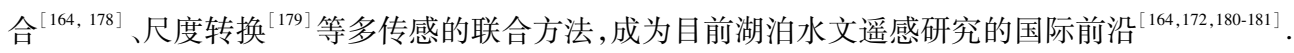

多源传感器海量卫星数据的使用, 给数据存储、管理及数据运算与分析能力带来了前所未有的挑战. 针 对这些问题,一些新的技术方法, 如计算机自动识别、机器学习、深度学习等算法逐渐兴起 ${ }^{[182]}$, 对湖泊水文 过程的认识和理解起到了积极的推动作用 ${ }^{[183-185]}$. 地球大数据时代, 将湖泊水情监测研究的需求与多时相遥 感信息处理技术优势结合,进一步发展高性能的分布式存储、云计算平台 (如 Google Earth Engine, EGG) 等 大数据处理技术, 将会有效提升湖泊水情遥感观测的潜力, 势必给湖泊水文学研究带来新的发展 机遇 ${ }^{[177,184]}$.

1.4.2 湖泊水文要素的宏观变化过程目前卫星遥感技术已经能够实现降水、蒸散发、湖泊水位、水域面积、 地下水、湖盆地形等湖泊水文要素的信息提取,尤其在水域面积、水位、蒸散发监测等方面取得了显著的进 展, 揭示了相关水文要素的宏观变化过程, 为湖泊水资源高效管理、生态环境保护及区域可持续发展提供了 科技支撑.

在湖泊面积变化分析方面,遥感技术已在全球各大、中、小型湖泊的变化过程分析中得到了广泛的应 用 $^{[4-5,162-163,186-189]}$. 尤其是定量遥感、时间序列分析和 GIS 空间分析等技术的有效结合, 揭示了湖泊水面的空 间格局、生消过程和时空变异 ${ }^{[190]}$, 深化了对水文要素宏观变化过程的认识 ${ }^{[191-192]}$. 基于遥感提取的长时序水 域面积,揭示了 2006 年鄱阳湖水文节律发生突变, 提供了湖泊水文系统状态转换的首个研究案例 ${ }^{[193]}$. 通过 分析不同干旱条件下的水文情势和变化特征 ${ }^{[194]}$, 阐述了鄱阳湖极端干旱事件的空间演变特征, 明晰了人湖 径流减少和长江顶托作用下降是导致鄱阳湖干旱的直接原因 ${ }^{[152]}$. 除了单个湖泊, 长江流域 ${ }^{[195-198]}$ 等湖泊群 也进人动态监测及研究视野. 研究表明, 1990 年之后, 青藏高原地区大多数湖泊均呈现扩张态势, 并且在 2000 年之后表现出扩张速率的增长 ${ }^{[199]}$, 而以鄱阳湖和洞庭湖为代表的东部湖群却呈现逐渐萎缩的 趋势 ${ }^{[190,200]}$.

在湖泊水位变化分析方面,在过去的 20 多年里, T/P、ERS、GFO、Envisat、Jason-1/2、ICESat 等多种卫星 高度计已相继用于不同类型湖泊的水位监测中, 但主要用于大型湖泊水体, 包括非洲大湖、中国大湖 等 ${ }^{[175-176,195,201-202]}$. 结合高分辨率 DEM 叠合法,运用遥感提取的湖泊水域空间分布信息, 也可获取湖泊水位的 空间分布, 平均相对误差为 $3 \sim 8 \mathrm{~cm}^{[203]}$. 例如, 运用光学遥感水域面积提取和 DEM 方法, 揭示了鄱阳湖水位 的空间分布特性及其季节变化规律, 阐释了丰水年、平水年和枯水年的湖区水位梯度变化特征, 以及极端干 旱条件下湖泊水位的空间涨落过程 ${ }^{[186]}$.

对于洪泛型湖泊,湖区周边控制性水文站以下区间产水量的估算始终是湖泊水文研究的难点,而通过 遥感反演获得湖区蒸散发量, 从而可以推求湖区产水量. 例如, 针对鄱阳湖水域面积变幅大这一空间特征, 可以利用温度一植被指数三角法或遥感蒸散非参数化 (RS-NP) 模型 ${ }^{[204]}$, 反演较长时序的湖区蒸散及其时空 变化特征, 剖析环境因子对湖区蒸散的影响 ${ }^{[205]}$. 这类研究为突破湖区产流估算瓶颈提供了新的解决途径, 有助于完善湖区水量平衡关系分析,增强湖泊水量变化溯源分析的可靠性.

\section{2 湖泊水文学的发展展望}

近 50 年来, 湖泊水文学在水文要素的观测和湖泊水文过程的模拟等方面取得了突出的进展, 揭示了水 文现象不同时间尺度的演变规律, 极大地丰富了水文学的内容,特别是在复合河湖系统的水动力过程模拟、 大型通江湖泊水文演变机理与洪旱过程模拟、湖泊一流域相互作用的气候水文分布式模拟等方面取得了可 喜的成果. 然而, 全球气候变化加速和社会经济的快速发展带来新的水资源问题, 给湖泊水文学提出了新的 要求和挑战. 当今, 我们在河湖水文系统的非线性特征及其演变、湖泊水文对气候变化和人类活动叠加作用 的响应机理与路径、湖泊水文在年代尺度上的变化趋势预测等方面研究还明显不足,制约了湖泊水文学在 湖泊水量调控技术、高强人类活动区域湖泊水资源的可持续利用、湖泊一流域水资源综合管理等方面的强大 科技支撑作用. 在湖泊水文基本规律、新型模拟预测方法和原位观测与数据融合等方面仍需开展深人的研 究. 本文归纳了以下几个方面作为今后重点研究的展望.

\section{1 强化湖泊与流域水文过程的一体化研究, 阐明流域对湖泊的影响机理及湖泊的反馈机制, 发展综合集成 模拟模型, 丰富湖泊水文学理论与方法}

湖泊与流域是一个整体, 两者通过大气、水系、土壤和地下含水层发生水量、物质和能量的输送. 传统湖 
泊水文学的研究多半以湖泊本身为研究对象, 流域输人只是作为一种外部条件加以考虑, 两者进行独立研 究, 导致从流域到湖泊的物质流和能量流被分割, 湖泊对来自大气、地表、土壤、含水层等不同介质的快、慢 速物质流的响应不能真实连续地加以考虑, 在认识流域至湖泊的传输途径和机制方面存在一定的局限 ${ }^{[124]}$. 再者, 湖泊对流域具有一定的反馈机制, 大型湖泊水体与大气之间的热量交换引发近地面大气的对流扩散 循环, 影响湖泊区域的降水量和近面气温 ${ }^{[206]}$. 将湖泊与流域作为一个整体加以研究, 通过多尺度观测数据 的融合和数学多模式耦合, 可有效地把水面与大气的水热交换反馈给流域模型, 有助于深人解释和全面认 识湖泊与流域的相互作用机制,辨识流域区域气候条件变化的湖泊影响机理.

将湖泊与流域作为整体加以研究, 需加强从流域到湖泊的系统观测, 建设从大气到地下含水层、从山区 到湖泊的垂、横向观测网, 获取同步的气象、水文、水动力、生态多要素观测数据. 随着观测方法和数据传输 技术的成熟, 构建覆盖多个湖泊流域的大联网观测系统已成为可能. 中国生态系统研究网络 (CERN) 已开始 论证建设长江中下游湖泊群的高频观测网设计 (CERN 野外观测论证会, 2018 年, 北京). 联网观测将显著提 高对不同湖泊流域定量对比研究的水平, 揭示湖泊组群对外部驱动因素变化的响应机理, 支撑流域一湖泊系 统大气、水文、覆被全过程多尺度耦合模型的研发, 提升湖泊水文演变规律和变化趋势的解析和预测能力.

2.2 完善多源遥感数据不同时空尺度的融合与验证方法, 提高湖泊水文要素的遥感监测精度, 加强与水文水 动力模型耦合, 揭示湖泊的宏观结构及变化过程, 拓展湖泊水文学研究手段

构建天一空一地一体化的综合立体监测网络, 将多源遥感数据与原位定点观测数据相结合, 开展湖泊水 文要素的宏观、实时、连续监测, 已经成为当前湖泊水文学研究的重要手段和学科能力建设的必备内容. 对 于全球变化趋势下的各种类型湖泊而言, 实现湖泊水文要素的长时序、精准监测, 仍然面临着一系列的技术 方法难点,包括不同分辨率数据的尺度转换、卫星传感器的绝对定标、反演精度的多尺度检验等 ${ }^{[158]}$.

在湖泊水文要素的宏观结构及变化过程研究方面, 需要进一步加强遥感数据与水文水动力模型两者之 间的深度融合. 综合运用水文学和遥感等多学科知识, 采用数据同化等新技术, 提高多源遥感数据与水文长 期定位观测数据之间的结合度, 是湖泊水文学研究的前沿和热点 ${ }^{[207]}$. 虽然湖泊水文遥感在揭示时空格局方 面表现出强大的空间细节捕捉能力, 但如何最大限度地发挥这一优势, 为湖泊水文过程等提供新的物理阐 释,也是今后面临的一个重要挑战.

\section{3 创新人类活动对湖泊流域水文过程影响机理的研究方法, 分辨湖泊极端水文事件发生的自然和人为因 素影响方式,支撑湖泊水旱灾害调控和水资源安全保障技术}

人类活动在各种时空尺度上对水资源的影响越发显著. 在亚洲等区域, 人类活动引起的水量消耗与全 球气候变化的影响程度是同一个数量级, 甚至超过气候变化的影响 ${ }^{[208]}$. 人类活动通过闸坝建设、湖泊围县、 泥沙开采、调水等, 改变湖泊的水文过程和水量平衡. 这些活动在不同时空尺度上交织在一起,叠加不同的 气候背景, 对湖泊水文过程的影响尤为复杂. 深人识别人类活动对湖泊水文过程的影响, 揭示其在湖泊水文 极值演变和极端水文事件发展中的作用机理,是湖泊水文学面临的现实挑战.

目前的研究主要基于人类活动相对较弱的历史基准期, 首先计算气候变化引起的水量增量, 从观测的 水量变幅中扣除该气候变化引起的增量, 余量即认为是人类活动影响的分量. 该方法假设气候变化和人类 活动的贡献是可以线性相加的, 但气候变化和人类活动的时间尺度不同, 人类活动往往在更短时间尺度上 对水量产生影响, 并可能产生累积效应 ${ }^{[209]}$. 简单与气候变化的影响进行叠加, 可能低估人类活动的影响强 度. 未来应加强人类活动定量表征的研究, 改进和完善动力关系, 发展新一代人与自然耦合的湖泊水文模 型,服务于湖泊水资源变化预测, 应对全球变化, 保障湖泊水安全.

\section{3 结语}

湖泊水文学发展历史悠长, 我国早期就有湖泊水文观测和记录的古籍. 1949 年以来, 我国对湖泊资源的 利用和重视推动了湖泊水文水资源研究的热潮, 极大地促进了湖泊水文学的发展, 建立了较为成熟的湖泊 水文学理论基础和成功的应用实践,保障了我国社会经济发展中湖泊水资源的科学利用.

进人 21 世纪以来, 气候变化呈现加速态势, 极端气候频繁出现, 叠加重大水利工程建设等人类活动的 影响, 河湖水文水动力过程变化显著, 湖泊水量在全球尺度上的分布格局发生显著的变化, 湖泊干旱和洪水 
频繁, 且呈越发严重的态势. 流域污染负荷有增不减,湖泊水质和生态呈恶化趋势. 解决区域发展与湖泊水 资源可持续利用的矛盾, 维持正常的水量供给和生态需水, 仍是当今和未来相当长一段时间内湖泊水文学 的重大任务和巨大挑战.

对地观测技术和原位长期定位观测技术的快速发展带来了数据的重大变革,汇集气象、水文、人文、经 济、生态、环境、政策、经验等各种信息的大数据时代已经到来,数据信息的变革赋予湖泊水文学新的内容, 其中最为显著的是对传统演算方法的挑战. 针对湖泊水资源出现的新问题和数据信息的多元化,迫切需要 发展新的水文计算方法, 以反映多要素、多信息、多过程的叠加效应, 开拓湖泊水文学的综合性研究. 此外, 湖泊与流域密切相关, 以湖泊及其流域为完整对象加以一体化研究,有助于体现两者之间的相互作用和反 馈机制, 完整表征湖泊一流域水文过程的演变规律和驱动因子, 促进湖泊水文和流域水文的协同发展, 丰富 相关的理论论述, 提升对湖泊一流域系统的长期预测能力和短期预报能力, 最大限度地防范全球变化带来的 风险, 化解湖泊的水问题危机,保障区域水资源安全.

致谢: 本文的成稿得到了同行专家和同事的支持和建议,在此一并致谢.

\section{4 参考文献}

[ 1 ] Messager ML, Lehner B, Grill G et al. Estimating the volume and age of water stored in global lakes using a geo-statistical approach. Nature Communications, 2016, 7: 13603. DOI: 10.1038/ncomms13603.

[ 2 ] Ma RH, Yang GH, Duan HT et al. China's lakes at present: Number, area and spatial distribution. Scientia Sinica Terrae, 2011, 41(3) : 394-401. [马荣华, 杨桂山, 段洪涛等. 中国湖泊的数量、面积与空间分布. 中国科学: 地球科学, 2011, 41(3) : 394-401.]

[ 3 ] Pekel JF, Cottam A, Gorelick N et al. High-resolution mapping of global surface water and its long-term changes. Nature, 2016, 540(7633) : 418-422. DOI: 10.1038/nature20584.

[ 4 ] Song CQ, Huang B, Richards K et al. Accelerated lake expansion on the Tibetan Plateau in the 2000s: Induced by glacial melting or other processes? Water Resources Research, 2014, 50(4) : 3170-3186. DOI: 10.1002/2013wr014724.

[ 5 ] Wang JD, Sheng YW, Tong TSD. Monitoring decadal lake dynamics across the Yangtze Basin downstream of Three Gorges Dam. Remote Sensing of Environment, 2014, 152 : 251-269. DOI: 10.1016/j.rse.2014.06.004.

[ 6 ] Zhang Q ed. Poyang Lake hydrological changes. Beijing: Science Press, 2018. [张奇. 鄱阳湖水文情势变化研究. 鄱阳 湖水文情势变化研究. 北京: 科学出版社, 2018.]

[ 7 ] Li YY, Zhang XP, Shang CP. Characteristics of summer precipitation in Dongting Lake basin and analysis of atmospheric circulation in drought and flood years. Journal of Meteorological Research and Application, 2018, 39(1) : 1-5, $23,153$. [黎炎炎隆, 章新平, 尚程鹏. 洞庭湖流域夏季降水特征及旱涝年份大气环流分析. 气象研究与应用, 2018, 39(1): $1-5,23,153$.

[ 8 ] Wang LZ, Hu QF, Wang YT et al. Comparison of the two flood events occurred in 2016 and 1991 in the Taihu Lake Basin. Journal of Hohai University: Natural Sciences, 2018, 46(6) : 471-478. [王否之, 胡庆芳, 王银堂等. 太湖流域 2016 年、1991 年大洪水对比分析. 河海大学学报：自然科学版, 2018, 46(6) : 471-478.]

[ 9 ] Yang GS, Zhang Q, Wan RR et al. Lake hydrology, water quality and ecology impacts of altered river-lake interactions: Advances in research on the middle Yangtze River. Hydrology Research, 2016, 47 ( S1): 1-7. DOI: 10. 2166/nh. 2016.003 .

[10] Wang SM, Dou HS eds. Chinese lakes. Beijing: Science Press, 1998. [王苏民, 窦鸿身. 中国湖泊志. 北京: 科学出版 社, 1998.]

[11］ Shi CX, Liang RJ eds. Principles of land surface hydrology. Beijing: China Industry Press, 1964. [施成熙, 梁瑞驹. 陆 地水文学原理. 北京: 中国工业出版社, 1964.]

[12] Frey DG, Goldman CR, Horne AJ. Limnology. Limnology and Oceanography, 1984, 29(2) : 447-447.

[13] Li GW, Yu ZW, Chen JL. Study on the relationship between dynamic level-area and level-volume of Poyang Lake. Jiangxi Hydraulic Science \& Technology, 2015, 41(1): 21-26, 34. [李国文, 喻中文, 陈家霖. 鄱阳湖动态水位 面积、水 位 容积关系研究. 江西水利科技, 2015, 41(1): 21-26, 34.]

[14] Zhang Q, Werner AD. Hysteretic relationships in inundation dynamics for a large lake-floodplain system. Journal of Hydrology, 2015, 527: 160-171. DOI: 10.1016/j.jhydrol.2015.04.068. 
[15] Zhang GQ, Yao TD, Shum CK et al. Lake volume and groundwater storage variations in Tibetan Plateau's endorheic basin. Geophysical Research Letters, 2017, 44(11) : 5550-5560. DOI: 10.1002/2017gl073773.

[16] Zhang XL, Zhang Q, Wang XL. Analysis on nonlinear hydrologic characteristics of stage-inflow relationship in Poyang Lake. Resources and Environment in the Yangtze Basin, 2017, 26(5): 723-729. [张小琳, 张奇, 王晓龙. 洪泛湖泊水 位-流量关系的非线性特征分析. 长江流域资源与环境, 2017, 26(5) : 723-729.]

[17] Wu HB. Studies on changes in water level and storage of Bosten Lake based on satellite-borne radar altimetry data. Journal of Water Resources \& Water Engineering, 2019, 30(3) : 9-16. [ 吴红波. 基于星载雷达测高资料估计博斯腾湖水位-水 量变化研究. 水资源与水工程学报, 2019, 30(3) : 9-16.]

[18] Bai L, Zhang Q, Li XH. Review on variation characteristics and the key impact factors of lake water quantity. Water Resources and Power, 2010, 28(3) : 30-35. [白丽, 张奇, 李相虎. 湖泊水量变化关键影响因子研究综述. 水电能源科 学, 2010, 28(3): 30-35.]

[19] Li YL, Zhang Q, Cai YJ et al. Hydrodynamic investigation of surface hydrological connectivity and its effects on the water quality of seasonal lakes: Insights from a complex floodplain setting (Poyang Lake, China). Science of the Total Environment, 2019, 660 : 245-259. DOI: 10.1016/j.scitotenv.2019.01.015.

[20] Sun ZD, Huang Q, Jiang JH et al. Recent hydrological droughts in Dongting Lake and its association with the operation of Three Gorges reservoir. Resources and Environment in the Yangtze Basin, 2015, 24(2) : 251-256. [孙占东, 黄群, 姜加 虎等. 洞庭湖近年干旱与三峡蓄水影响分析. 长江流域资源与环境, 2015, 24(2) : 251-256.]

[21] Zhang T, Wu JF, Lin J et al. Analysis of water level change of Bosten Lake based on water balance. Journal of China Hydrology, 2015, 35(3): 78-83. [张涛, 吴剑锋, 林锦等. 基于水量平衡的博斯腾湖水位变化分析. 水文, 2015, 35 (3) : 78-83.]

[22] Guo MJ, Zhou XD, Li P et al. Investigation of the changes in the water level of Bosten Lake in the past 50 years. Research of Soil and Water Conservation, 2015, 22(2): 52-57. [ 郭梦京, 周孝德, 李鹏等. 近 50 年博斯腾湖水位变化特征分 析. 水土保持研究, 2015, 22(2): 52-57.]

[23] Conant BJ, Robinson CE, Hinton MJ et al. A framework for conceptualizing groundwater-surface water interactions and identifying potential impacts on water quality, water quantity, and ecosystems. Journal of Hydrology, 2019, 574: 609-627. DOI: $10.1016 /$ j.jhydrol.2019.04.050.

[24] Javed A, Cheng VYS, Arhonditsis GB. Detection of spatial and temporal hydro-meteorological trends in Lake Michigan, Lake Huron and Georgian Bay. Aquatic Ecosystem Health \& Management, 2019, 22(1) : 1-14. DOI: 10.1080/14634988. 2018.1500850

[25] Dessie M, Verhoest NEC, Pauwels VRN et al. Water balance of a lake with floodplain buffering: Lake Tana, Blue Nile Basin, Ethiopia. Journal of Hydrology, 2015, 522 : 174-186. DOI: 10.1016/j.jhydrol.2014.12.049.

[26] Kummu M, Tes S, Yin S et al. Water balance analysis for the Tonle Sap Lake-floodplain system. Hydrological Processes, 2014, 28(4) : 1722-1733. DOI: 10.1002/hyp.9718

[27] Tan Z, Melack J, Li Y et al. Estimation of water volume in ungauged, dynamic floodplain lakes. Environmental Research Letters , 2020, 15(5) : 054021. DOI: 10.1088/1748-9326/ab82cb.

[28] McDonnell JJ. Beyond the water balance. Nature Geoscience, 2017, 10(6) : 396. DOI: 10.1038/ngeo2964.

[29] Berghuijs WR, Allen ST. Waters flowing out of systems are younger than the waters stored in those same systems. Hydrological Processes, 2019, 33(25) : 3251-3254. DOI: 10.1002/hyp.13569.

[30] Liu XY, Chen JS, Tan HB et al. Estimation of lake leakage by stable isotope $\delta^{18}$ O. Nuclear Techniques, 2010, 33(10): 57-60. [刘晓艳, 陈建生, 谭红兵等. 利用稳定同位素 $\delta^{18} \mathrm{O}$ 估算湖泊渗漏量. 核技术, 2010, 33(10) : 57-60.]

[31] Chen JS, Ji BC, Liu Z et al. Isotopic and hydro-chemical evidence on the origin of groundwater through deep-circulation ways in Lake Daihai region, Inner Mongolia plateau. J Lake Sci, 2013, 25(4) : 521-530. DOI: 10.18307/2013.0409. [陈建生, 季弶宸, 刘震等. 内蒙古高原岱海接受远程深循环地下水补给的环境同位素及水化学证据. 湖泊科学, 2013, 25 (4) : 521-530.]

[32] Li YL, Zhang Q, Yao J et al. Assessment of water storage response to surface hydrological connectivity in a large floodplain system (Poyang Lake, China) using hydrodynamic and geostatistical analysis. Stochastic Environmental Research and Risk Assessment, 2019, 33(11/12) : 2071-2088. DOI: 10.1007/s00477-019-01740-9.

[33] Li YL, Zhang Q, Lu JR et al. Assessing surface water-groundwater interactions in a complex river-floodplain wetland-isola- 
ted lake system. River Research and Applications, 2019, 35(1) : 25-36. DOI: 10.1002/rra.3389.

[34] Tan ZQ, Wang XL, Chen B et al. Surface water connectivity of seasonal isolated lakes in a dynamic lake-floodplain system. Journal of Hydrology, 2019, 579: 124154. DOI: 10.1016/j.jhydrol.2019.124154.

[35] Liu XG, Zhang Q, Li YL et al. Satellite image-based investigation of the seasonal variations in the hydrological connectivity of a large floodplain (Poyang Lake, China). Journal of Hydrology, 2020, 585: 124810. DOI: 10. 1016/j. jhydrol. 2020.124810 .

[36] Ye XC, Zhang Q, Bai L et al. A modeling study of catchment discharge to Poyang Lake under future climate in China. Quaternary International, 2011, 244(2) : 221-229. DOI: 10.1016/j.quaint.2010.07.004.

[37] Guo H, Hu Q, Zhang Q et al. Effects of the Three Gorges Dam on Yangtze River flow and river interaction with Poyang Lake, China: 2003-2008. Journal of Hydrology, 2012, 416/417: 19-27. DOI: 10.1016/j.jhydrol.2011.11.027.

[38] Zhang Q, Li L, Wang YG et al. Has the Three-Gorges Dam made the Poyang Lake wetlands wetter and drier? Geophysical Research Letters, 2012, 39(20) : 2012GL053431. DOI: 10.1029/2012gl053431.

[39] Liu YB, Zhao XS, Wu GP. A primary investigation on the formation of frequent droughts in the Poyang Lake Basin in recent decade. Resources and Environment in the Yangtze Basin, 2014, 23(1): 131-138. [刘元波, 赵晓松, 吴桂平. 近十 年鄱阳湖区极端干旱事件频发现象成因初析. 长江流域资源与环境, 2014, 23(1): 131-138.]

[40] Li YL, Zhang Q, Werner AD et al. Investigating a complex lake-catchment-river system using artificial neural networks: Poyang Lake (China). Hydrology Research, 2015, 46(6) : 912-928. DOI: 10.2166/nh.2015.150.

[41] Huang AN, Rao YR, Lu YY et al. Hydrodynamic modeling of Lake Ontario: An intercomparison of three models. Journal of Geophysical Research: Atmospheres, 2010, 115(C12) : C12076. DOI: 10.1029/2010jc006269.

[42] Zhang Q, Werner AD. Integrated surface-subsurface modeling of Fuxianhu Lake catchment, southwest China. Water Resources Management, 2009, 23(11) : 2189-2204. DOI: 10.1007/s11269-008-9377-y.

[43] Zhang Q, Li LJ. Development and application of an integrated surface runoff and groundwater flow model for a catchment of Lake Taihu watershed, China. Quaternary International, 2009, 208 (1/2) : 102-108. DOI: 10. 1016/j. quaint. 2008. 10.015 .

[44] Wuebbles DJ, Hayhoe K, Parzen J. Introduction: Assessing the effects of climate change on Chicago and the great lakes. Journal of Great Lakes Research, 2010, 36: 1-6. DOI: 10.1016/j.jglr.2009.09.009.

[45] Li YL, Tao H, Yao J et al. Application of a distributed catchment model to investigate hydrological impacts of climate change within Poyang Lake catchment (China). Hydrology Research, 2016, 47 ( S1 ) : 120-135. DOI: 10.2166/nh. 2016.234.

[46] Prudhomme C, Giuntoli I, Robinson EL et al. Hydrological droughts in the 21st century, hotspots and uncertainties from a global multimodel ensemble experiment. Proceedings of the National Academy of Sciences of the United States of America, 2014, 111(9) : 3262-3267. DOI: 10.1073/pnas.1222473110.

[47] Ung P, Peng C, Yuk S et al. Dynamics of bacterial community in Tonle Sap Lake, a large tropical flood-pulse system in Southeast Asia. Science of the Total Environment, 2019, 664: 414-423. DOI: 10.1016/j.scitotenv.2019.01.351.

[48] Ou CM, Yin H, Zhang L. Risk-loss assessment of agricultural flood and drought in different scenarios in Dongting Lake area. Research of Agricultural Modernization, 2011, 32(6) : 691-694. [欧朝敏, 尹辉, 张否. 洞庭湖区不同情景下农业 水旱灾害风险损失评估. 农业现代化研究, 2011, 32(6) : 691-694.]

[49] Sun ZD, Groll M, Opp C. Lake-catchment interactions and their responses to hydrological extremes. Quaternary International, 2018, 475: 1-3. DOI: 10.1016/j.quaint.2018.04.029.

[50] Shabani A, Zhang XD, Chu XF et al. Mitigating impact of Devils Lake flooding on the Sheyenne River sulfate concentration. JAWRA Journal of the American Water Resources Association, 2020, 56 (2): 297-309. DOI: 10. 1111/17521688.12825 .

[51] Li Q, Zhao CZ, Wang JW et al. Morphological and photosynthetic physiological characteristics of Saussurea salsa in response to flooding in salt marshes of Xiao Sugan Lake, Gansu, China. China Journal of Plant Ecology, 2019, 43(8) : 685-696. [李群, 赵成章, 王继伟等. 甘肃小苏干湖盐沼湿地盐地风毛菊叶形态-光合生理特征对淹水的响应. 植 物生态学报, 2020, 43(8): 685-696.]

[52] Kuang YW, Ma ZH. Analysis of extraordinary flood in Dongting Lake Basin in 2017. Journal of China Hydrology, 2019, 39(3) : 92-96. [ 匡燕武，马忠红. 2017 年洞庭湖特大洪水分析. 水文, 2019, 39(3) : 92-96.] 
[53] Yin ZJ, Wang R, Li L et al. Analysis of storm flood occurred in the Yangtze River basin in July, 2017. Journal of China Hydrology, 2019, 39(2) : 88-93. [尹志杰, 王容, 李否等. 长江流域 “2017・07”暴雨洪水分析. 水文, 2019, 39 (2) : 88-93.]

[54] Lei YB, Zhu YL, Wang B et al. Extreme lake level changes on the Tibetan Plateau associated with the 2015/2016 El niño. Geophysical Research Letters, 2019, 46(11) : 5889-5898. DOI: 10.1029/2019gl081946.

[55] Zhang LP, Du H, Xia J et al. Progress in the study of extreme hydrologic events under climate change. Progress in Geogra$p h y, 2011,30(11): 1370-1379$. [张利平, 杜鸿, 夏军等. 气候变化下极端水文事件的研究进展. 地理科学进展, 2011, 30(11): 1370-1379. ]

[56] Beniston M, Stephenson DB, Christensen OB et al. Future extreme events in European climate: An exploration of regional climate model projections. Climatic Change, 2007, 81(S1) : 71-95. DOI: 10.1007/s10584-006-9226-z.

[57] Alsdorf DE, Melack JM, Dunne T et al. Interferometric radar measurements of water level changes on the Amazon flood plain. Nature, 2000, 404(6774) : 174-177. DOI: 10.1038/35004560.

[58 ] Li TY, Li SY, Bush RT et al. Extreme drought decouples silicon and carbon geochemical linkages in lakes. Science of the Total Environment, 2018, 634: 1184-1191. DOI: 10.1016/j.scitotenv.2018.04.074.

[59] Zhang K, Xu M, Wu QL et al. The response of zooplankton communities to the 2016 extreme hydrological cycle in floodplain lakes connected to the Yangtze River in China. Environmental Science and Pollution Research, 2018, 25(23): 23286-23293. DOI: 10.1007/s11356-018-2144-6.

[60] Buma WG, Lee SI. Multispectral image-based estimation of drought patterns and intensity around Lake Chad, Africa. Remote Sensing, 2019, 11(21) : 2534. DOI: 10.3390/rs11212534.

[61] Bolgov MV, Buber AL, Korobkina EA et al. Lake Baikal: Extreme level as a rare hydrological event. Water Resources, 2017, 44(3) : 522-536. DOI: 10.1134/s009780781703006x.

[62] Min Q, Min D. Drought change characteristics and drought protection countermeasures for Poyanghu Lake basin. Journal of China Hydrology, 2010, 30 (1) : 84-88. [闵骞, 闵聑. 鄱阳湖区干旱演变特征与水文防旱对策. 水文, 2010, 30 (1) : 84-88.]

[63] Li XH, Zhang Q, Hu Q et al. Lake flooding sensitivity to the relative timing of peak flows between upstream and downstream waterways: A case study of Poyang Lake, China. Hydrological Processes, 2017, 31(23) : 4217-4228. DOI: 10. 1002/hyp.11362.

[64] Zhu JG, Deng JC, Zhang YH et al. Response of submerged aquatic vegetation to water depth in a large shallow lake after an extreme rainfall event. Water, 2019, 11(11) : 2412. DOI: 10.3390/w11112412.

[65] Zhang XK, Liu XQ, Yang ZD et al. Restoration of aquatic plants after extreme flooding and drought: A case study from Poyang Lake National Nature Reserve. Applied Ecology and Environmental Research, 2019, 17 (6) : 15657-15668. DOI: 10.15666/aeer/1706_1565715668.

[66] Carter E, Steinschneider S. Hydroclimatological drivers of extreme floods on Lake Ontario. Water Resources Research, 2018, 54(7) : 4461-4478. DOI: 10.1029/2018wr022908.

[67] Jalbert J, Murphy OA, Genest C et al. Modelling extreme rain accumulation with an application to the 2011 Lake Champlain flood. Journal of the Royal Statistical Society Series C-Applied Statistics, 2019, 68(4) : 831-858. DOI: 10.1111/ rssc. 12342.

[68] Paynter S, Nachabe M. Use of generalized extreme value covariates to improve estimation of trends and return frequencies for lake levels. Journal of Hydroinformatics, 2011, 13(1) : 13-24. DOI: 10.2166/hydro.2010.077.

[69] Liu Y, Wu G. Hydroclimatological influences on recently increased droughts in China's largest freshwater lake. Hydrology and Earth System Sciences, 2016, 20(1) : 93-107. DOI: 10.5194/hess-20-93-2016.

[70] Zhang D, Chen P, Zhang Q et al. Copula-based probability of concurrent hydrological drought in the Poyang Lake-catchment-river system (China) from 1960 to 2013. Journal of Hydrology, 2017, 553: 773-784. DOI: 10.1016/j. jhydrol. 2017.08.046.

[71] Shankman D, Keim BD, Song J. Flood frequency in China's Poyang Lake region: Trends and teleconnections. International Journal of Climatology, 2006, 26(9) : 1255-1266. DOI: 10.1002/joc.1307.

[72] Nandintsetseg B, Greene JS, Goulden CE. Trends in extreme daily precipitation and temperature near Lake Hövsgöl, Mongolia. International Journal of Climatology, 2007, 27(3) : 341-347. DOI: 10.1002/joc.1404. 
[73] Yao J, Li YL, Li MF et al. The influence of bathymetry changes on low water level of Lake Poyang. J Lake Sci, 2017, 29 (4) : 955-964. DOI: 10.18307/2017.0419. [姚静, 李云良, 李梦凡等. 地形变化对鄱阳湖枯水的影响. 湖泊科学, $2017,29(4): 955-964$. $]$

[74] Dai ML, Shen YZ. Encountered regulation research on upstream flood of Yangtze River with Dongting Lake flood. Journal of Water Resources \& Water Engineering, 2010, 21(6) : 117-120. [ 戴明龙, 沈燕舟. 长江上游与洞庭湖洪水遭遇规律 研究. 水资源与水工程学报, 2010, 21(6): 117-120.]

[75] Sun SR, Xie P, Zhao HY et al. Variability in the annual flood peak discharge and water level in three outlets of Lake Dongting. J Lake Sci, 2018, 30(3) : 812-824. DOI: 10.18307/2018.0323. [孙思瑞, 谢平, 赵江艳等. 洞庭湖三口洪 峰流量和水位变异特性分析. 湖泊科学, 2018, 30(3): 812-824.]

[76] Sun KK, Chen J. Ecological effect of typical flood and drought process on lake wetlands. Journal of Yangtze River Scientific Research Institute, 2013, 30(5) : 5-8, 12. [孙可可, 陈进. 典型洪水和干旱过程对湖泊湿地的生态作用. 长江科学 院院报, 2013, 30(5): 5-8, 12.]

[77] Zhang Q, Ye XC, Werner AD et al. An investigation of enhanced recessions in Poyang Lake: Comparison of Yangtze River and local catchment impacts. Journal of Hydrology, 2014, 517: 425-434. DOI: 10.1016/j.jhydrol.2014.05.051.

[78] Ghale YAG, Altunkaynak A, Unal A. Investigation anthropogenic impacts and climate factors on drying up of Urmia Lake using water budget and drought analysis. Water Resources Management, 2018, 32(1) : 325-337. DOI : 10.1007/s11269017-1812-5.

[79] Satgé F, Espinoza R, Zolá R et al. Role of climate variability and human activity on Poopó Lake droughts between 1990 and 2015 assessed using remote sensing data. Remote Sensing, 2017, 9(3) : 218. DOI: 10.3390/rs9030218.

[80] Biron S, Assani AA, Frenette JJ et al. Comparison of Lake Ontario and St. Lawrence River hydrologic droughts and their relationship to climate indices. Water Resources Research, 2014, 50(2) : 1396-1409. DOI: 10.1002/2012wr013441.

[81] Assani AA, Landry R, Azouaoui $\mathrm{O}$ et al. Comparison of the characteristics (frequency and timing) of drought and wetness indices of annual mean water levels in the five north American great lakes. Water Resources Management, 2016, 30(1) : 359-373. DOI: $10.1007 / \mathrm{s} 11269-015-1166-9$.

[82] Li JB, Yu G, Ou CM et al. Evolution characters and influence factors of agricultural flood and drought in Dongting Lake area: diagnosis of' disaster situation in recent 60 years. Journal of Natural Disasters, 2011, 20(2): 74-81. [李景保, 余 果, 欧朝敏等. 洞庭湖区农业水旱灾害演变特征及影响因素—60 年来的灾情诊断. 自然灾害学报, 2011, 20 (2) : 74-81.]

[83] Guo H, Zhang Q, Wang YJ. Annual variations in climatic and hydrological processes and related flood and drought occurrences in the Poyang Lake Basin. Acta Geographica Sinica, 2012, 67(5) : 125-135. [郭华, 张奇, 王艳君. 鄱阳湖流域 水文变化特征成因及旱涝规律. 地理学报, 2012, 67(5): 125-135.]

[84] Tian R, Cao C, Ma G et al. Analysis of the difference and genetic in drought degree of Honghu Lake and Liangzi Lake in 2011. Journal of Geo-Information Science, 2014, 16(4) : 653-663.

[85] Zola RP, Bengtsson L. Long-term and extreme water level variations of the shallow Lake Poopo, Bolivia. Hydrological Sciences Journal-Journal Des Sciences Hydrologiques, 2006, 51(1) : 98-114. DOI: 10.1623/hysj.51.1.98.

[86] Shiri J, Shamshirband S, Kisi O et al. Prediction of water-level in the Urmia Lake using the extreme learning machine approach. Water Resources Management, 2016, 30(14) : 5217-5229. DOI: 10.1007/s11269-016-1480-x.

[87] Liu HY, Deng B, Liu YZ et al. Preliminary numerical analysis of the efficiency of a central lake reservoir in enhancing the flood and drought resistance of Dongting Lake. Water, 2018, 10(2) : 225. DOI: 10.3390/w10020225.

[88] Abbasi A, Khalili K, Behmanesh J et al. Drought monitoring and prediction using SPEI index and gene expression programming model in the west of Urmia Lake. Theoretical and Applied Climatology, 2019, 138(1/2) : 553-567. DOI: 10. 1007/s00704-019-02825-9.

[89] Riboust P, Brissette F. Climate change impacts and uncertainties on spring flooding of Lake Champlain and the Richelieu River. Journal of the American Water Resources Association, 2015, 51(3) : 776-793. DOI: 10.1111/jawr.12271.

[90] Shankman D, Keim BD, Nakayama T et al. Hydroclimate analysis of severe floods in China's Poyang Lake region. Earth Interactions, 2012, 16(14) : 1-16. DOI: 10.1175/2012ei000455.1.

[91] Ye ZW. A basic analysis on the characteristic and mechanism of the flood disaster in Hongze Lake. Research of Soil and Water Conservation, 2006, 13(4) : 90-92, 273. [叶正伟. 淮河洪泽湖洪涝灾害特征与成灾本底机理分析. 水土保持 
研究, 2006, 13(4) : 90-92, 273.]

[92] Li XH, Yao J, Li YL et al. A modeling study of the influences of Yangtze River and local catchment on the development of floods in Poyang Lake, China. Hydrology Research, 2016, 47 (S1) : 102-119. DOI: 10.2166/nh.2016.198.

[93] Li YL, Zhang Q, Werner AD et al. The influence of river-to-lake backflow on the hydrodynamics of a large floodplain lake system (Poyang Lake, China). Hydrological Processes, 2017, 31(1) : 117-132. DOI: 10.1002/hyp.10979.

[94] Zhang B, Schwartz FW, Liu GM. Systematics in the size structure of prairie pothole lakes through drought and deluge. Water Resources Research, 2009, 45(4): W04412. DOI: 10.1029/2008wr006878.

[95] Yao J, Zhang Q, Li YL et al. Hydrological evidence and causes of seasonal low water levels in a large river-lake system: Poyang Lake, China. Hydrology Research, 2016, 47 (S1) : 24-39. DOI: 10.2166/nh.2016.044.

[96] Wang Q, Yan DH, Qin TL et al. Impacts of human activities on drought of Baiyangdian Lake. Wetland Science, 2013,11 (4) : 475-481. [王青, 严登华, 秦天玲等. 人类活动对白洋淀干旱的影响. 湿地科学, 2013, 11(4) : 475-481.]

[97] Wüest A, Lorke A. Small -scale hydrodynamics in lakes. Annual Review of Fluid Mechanics, 2003, 35(1) : 373-412. DOI: 10.1146/annurev.fluid.35.101101.161220.

[98 ] Liang RJ, Zhong JH. A three-dimensional numerical simulation of wind-driven water current in Taihu Lake. J Lake Sci, 1994, 6(4) : 289-297. DOI: 10.18307/1994.0401. [梁瑞驹, 仲金华. 太湖风生流的三维数值模拟. 湖泊科学, $1994,6(4): 289-297$.

[99] Qin BQ, Hu WP, Chen WM et al. Studies on the hydrodynamic processes and related factors in Meiliang Bay, Northern Taihu Lake, China. J Lake Sci, 2000, 12(4) : 327-334. DOI : 10.18307/2000.0406. [秦伯强, 胡维平, 陈伟民等. 太 湖梅梁湾水动力及相关过程的研究. 湖泊科学, $2000,12(4): 327-334$.

[100] Shi CX. Current status and prospects of lake hydrological research. Journal of China Hydrology, 1988, (6) : 58-62. [施 成熙. 湖泊水文科学研究现状及展望. 水文, 1988，(6): 58-62.]

[101] Zhang YH, Lai XJ, Zhang L et al. The influence of aquatic vegetation on flow structure and sediment deposition: A field study in Dongting Lake, China. Journal of Hydrology, 2020, 584: 124644. DOI: 10.1016/j.jhydrol.2020.124644.

[102] León LF, Imberger JR, Smith REH et al. Modeling as a tool for nutrient management in Lake Erie: A hydrodynamics study. Journal of Great Lakes Research, 2005, 31(S2) : 309-318. DOI: 10.1016/s0380-1330(05)70323-3.

[103] Anderson EJ, Schwab DJ. Relationships between wind-driven and hydraulic flow in Lake St. Clair and the St. Clair River Delta. Journal of Great Lakes Research, 2011, 37(1) : 147-158. DOI: 10.1016/j.jglr.2010.11.007.

[104] Chen CS, Xu QC, Ralph E et al. Response of Lake Superior to mesoscale wind forcing: A comparison between currents driven by QuikSCAT and buoy winds. Journal of Geophysical Research: Oceans, 2004, 109( C10) : S02C10. DOI: 10. 1029/2002jc001692.

[105] McCombs MP, Mulligan RP, Boegman L et al. Modeling surface waves and wind-driven circulation in eastern Lake Ontario during winter storms. Journal of Great Lakes Research, 2014, 40: 130-142. DOI: 10.1016/j.jglr.2014.02.009.

[106] Zhu YC, Cai QM. Studies on a three-dimensional hydro-dynamic model for Meiliang Bay, Taihu Lake- I . Model description and result interpretation. Ocenologia et Limnologa Sinica, 1998, 29(1) : 79-85 [ 朱永春, 蔡启铭. 太湖梅梁湾三维 水动力学的研究— I I 模型的建立及结果分析. 海洋与湖沼, 1998, 29(1) : 79-85.]

[107] Jiang JH. Numerical modelling of wind-driven currents in Gonghu Lake and related lakes. Transections of Oceanology and Limnology, 1997，(4)：1-7. [姜加虎. 贡湖及其相关水域风生流模拟研究. 海洋湖沼通报，1997，(4)：1-7.]

[108] Hu WP, Qin BQ, Pu PM. Three-dimensional numerical experiments on hydrodynamics inTaihu Lake-3. Influences of reclamation in Mashan District on wind-driven current. J Lake Sci, 2000, 12(4) : 335-342. DOI: 10.18307/2000.0407. [胡维平, 秦伯强, 緩培民. 太湖水动力学三维数值试验研究- - 3. 马山围剭对太湖风生流的影响. 湖泊科学, 2000, 12(4): 335-342.]

[109] Pang Y, Pu PM, Gao G et al. Numerical simulations and their verification with ununiform wind stress in Taihu Lake. Transections of Oceanology and Limnology, 1994，(4) : 9-15. [逢勇, 誉培民, 高光等. 非均匀风场作用下太湖风成流风 涌水的数值模拟及验证. 海洋湖沼通报, 1994, (4) : 9-15.]

[110] Wang QQ, Jiang JH, Pu PM et al. numerical simulations and their verifications with one station data of wind-driven surge and currents in Taihu Lake. J Lake Sci, 1992, 4(4) : 1-7. DOI: 10.18307/1992.0401. [王谦谦, 姜加虎, 兴培民等. 太湖和大浦河口风成流、风涌水的数值模拟及其单站验证. 湖泊科学, 1992, 4(4): 1-7.]

[111] Pang Y, Pu PM. Numerical simulation of three-dimensional wind-driven current in Taihu Lake. Acta Geographica Sinica, 
1996, 51(4) : 322-328. [逢勇, 㵙培民. 太湖风生流三维数值模拟试验. 地理学报, 1996, 51(4) : 322-328.]

[112] Hu WP, Pu PM, Qin BQ et al. A three-dimensional numerical simulation on the dynamics in Taihu Lake, China- I : the water level and the current during the 9711 typhoon process. J Lake Sci, 1998, 10(4) : 17-25. DOI: 10.18307/1998. 0403. [胡维平, 誉培民, 秦伯强等. 太湖水动力学三维数值试验研究—-1. 风生流和风涌增减水的三维数值模 拟. 湖泊科学, 1998, 10(4): 17-25.]

[113] Li YP, Pang Y, Xu QX. Simulation of transparency and its factors in Taihu Lake under hydrodynamic conditions. Journal of Hohai University: Natural Sciences, 2009, 37(6) : 625-630. [李一平, 逢勇, 徐秋霞等. 动水条件下太湖水体透明 度及其影响因子模拟. 河海大学学报: 自然科学版, 2009, 37(6) : 625-630.]

[114] Wu TF, Qin BQ, Zhu GW et al. Modeling of turbidity dynamics caused by wind-induced waves and current in the Taihu Lake. International Journal of Sediment Research, 2013, 28(2) : 139-148. DOI: 10.1016/s1001-6279(13)60026-8.

[115] Wu TF, Qin BQ, Brookes JD et al. Spatial distribution of sediment nitrogen and phosphorus in Lake Taihu from a hydrodynamics-induced transport perspective. Science of the Total Environment, 2019, 650: 1554-1565. DOI: 10. 1016/j. scitotenv.2018.09.145.

[116] Ma SW, Cai QM. Numerical study on the distribution of TP in Taihu Lake and the impact from lake current. J Lake Sci, 1997, 9(4) : 325-330. DOI: 10.18307/1997.0406. [马生伟, 蔡启铭. 太湖水体的总磷分布及湖流对其影响的数值 研究. 湖泊科学, 1997, 9(4) : 325-330.]

[117] Wu ZS, Cai YJ, Liu X et al. Temporal and spatial variability of phytoplankton in Lake Poyang: The largest freshwater lake in China. Journal of Great Lakes Research, 2013, 39(3): 476-483. DOI: 10.1016/j.jglr.2013.06.008.

[108] Li YP, Acharya K, Yu ZB. Modeling impacts of Yangtze River water transfer on water ages in Lake Taihu, China. Ecological Engineering, 2011, 37(2) : 325-334. DOI: 10.1016/j.ecoleng.2010.11.024.

[109] Li W, Qin BQ, Zhang YL et al. Numerical forecasting of short-term algae-induced black bloom in eutrophic shallow lake: A case study of Lake Taihu. J Lake Sci, 2016, 28(4) : 701-709. DOI: 10.18307/2016.0402. [李未, 秦伯强, 张运林 等. 富营养化浅水湖泊藻源性湖泛的短期数值预报方法——太湖为例. 湖泊科学, 2016, 28(4): 701-709.]

[120] Wang YP, Hu WP, Peng ZL et al. Predicting lake eutrophication responses to multiple scenarios of lake restoration: A three-dimensional modeling approach. Water, 2018, 10(8) : 994. DOI: 10.3390/w10080994.

[121] Hu WP. A review of the models for Lake Taihu and their application in lake environmental management. Ecological Modelling, 2016, 319: 9-20. DOI: 10.1016/j.ecolmodel.2015.07.028.

[122] Lai XJ, Jiang JH, Liang QH et al. Large-scale hydrodynamic modeling of the middle Yangtze River Basin with complex river-lake interactions. Journal of Hydrology, 2013, 492 : 228-243. DOI: 10.1016/j.jhydrol.2013.03.049.

[123] Lai XJ, Jiang JH, Huang Q. A coupling hydrodynamic model on water system of the Dongting lake area. Oceanologia et Limnologia Sinica, 2008, 39(1) : 74-81. [赖锡军, 姜加虎, 黄群. 洞庭湖地区水系水动力耦合数值模型. 海洋与湖 沼, 2008, 39(1) : 74-81.]

[124] Li YL, Zhang Q, Yao J et al. Hydrodynamic and hydrological modeling of the Poyang Lake catchment system in China. Journal of Hydrologic Engineering, 2014, 19(3) : 607-616. DOI: 10.1061/(asce) he.1943-5584.0000835.

[125] Lain XJ, Jiang JH, Huang Q et al. Two-dimensional numerical simulation of hydrodynamic and pollutant transport for Lake Poyang. J Lake Sci , 2011, 23(6) : 893-902. DOI: 10.18307/2011.0611. [赖锡军, 姜加虎, 黄群等. 鄱阳湖二维水动 力和水质耦合数值模拟. 湖泊科学, $2011, \mathbf{2 3}(6): 893-902$. ]

[126] Lai XJ, Huang Q, Zhang YH et al. Impact of lake inflow and the Yangtze River flow alterations on water levels in Poyang Lake, China. Lake and Reservoir Management, 2014, 30(4) : 321-330. DOI : 10.1080/10402381.2014.928390.

[127] Lai XJ, Liang QH, Jiang JH et al. Impoundment effects of the Three-Gorges-Dam on flow regimes in two China's largest freshwater lakes. Water Resources Management, 2014, 28(14) : 5111-5124. DOI: 10.1007/s11269-014-0797-6.

[128] Lai XJ, Shankman D, Huber C et al. Sand mining and increasing Poyang Lake's discharge ability: A reassessment of causes for lake decline in China. Journal of Hydrology, 2014, 519: 1698-1706. DOI: 10.1016/j.jhydrol.2014.09.058.

[129] Yao J, Zhang Q, Ye XC et al. Quantifying the impact of bathymetric changes on the hydrological regimes in a large floodplain lake: Poyang Lake. Journal of Hydrology, 2018, 561 : 711-723. DOI: 10.1016/j.jhydrol.2018.04.035.

[130] Yao J, Zhang D, Li YL et al. Quantifying the hydrodynamic impacts of cumulative sand mining on a large river-connected floodplain lake: Poyang Lake. Journal of Hydrology, 2019, 579: 124156. DOI: 10.1016/j.jhydrol.2019.124156.

[131] Yao J, Li YL, Zhang D et al. Wind effects on hydrodynamics and implications for ecology in a hydraulically dominated riv- 
er-lake floodplain system: Poyang Lake. Journal of Hydrology, 2019, 571: 103-113. DOI: 10. 1016/j. jhydrol. 2019. 01.057.

[132] Li YL, Zhang Q, Ye R et al. 3D hydrodynamic investigation of thermal regime in a large river-lake-floodplain system (Poyang Lake, China). Journal of Hydrology, 2018, 567: 86-101. DOI: 10.1016/j.jhydrol.2018.10.007.

[133] Wang P, Lai GY, Huang XL et al. Simulation of the impact of Lake Poyang Project on the dynamic of lake water level. J Lake Sci, 2014, 26(1) : 29-36. DOI: 10.18307/2014.0104. [王鹏, 赖格英, 黄小兰等. 鄱阳湖水利枢纽工程对湖泊 水位变化影响的模拟. 湖泊科学, 2014, 26(1): 29-36.]

[134] Lai GY, Wang P, Huang XL et al. A simulation research of impacts of the Lake Poyang hydraulic project on hydrology and hydrodynamics. J Lake Sci, 2015, 27 (1) : 128-140. DOI: 10.18307/2015.0116. [赖格英, 王鹏, 黄小兰等. 鄱阳湖水 利枢纽工程对鄱阳湖水文水动力影响的模拟. 湖泊科学, 2015, 27(1): 128-140.]

[135] Du YL, Zhou HD, Peng WQ et al. Modeling the impacts of the change of river-lake relationship on the hydrodynamic and water quality revolution in Poyang Lake. Acta Scientiae Circumstantiae, 2015, 35(5): 1274-1284. [杜彦良, 周怀东, 彭 文启等. 近 10 年流域江湖关系变化作用下鄱阳湖水动力及水质特征模拟. 环境科学学报, 2015, 35(5): 1274-1284.]

[136] Qi HD, Lu JZ, Chen XL et al. Water age prediction and its potential impacts on water quality using a hydrodynamic model for Poyang Lake, China. Environmental Science and Pollution Research, 2016, 23(13) : 13327-13341. DOI: 10.1007/ s11356-016-6516-5.

[137] Wang H, Zhao YJ, Zhou FN et al. Suspended sediment distribution under varied currents in the largest river-connected lake of China. Water Supply, 2018, 18(3): 994-1004. DOI: 10.2166/ws.2017.167.

[138] Tang CX, Xiong X, Wu NH et al. Simulation of the impact of the reverse flow from Yangtze River on the hydrodynamic process of Lake Poyang. J Lake Sci, 27(4) : 700-710. DOI: 10.18307/2015.0419. [唐昌新, 熊雄, 鸟年华等. 长江倒 灌对鄱阳湖水动力特征影响的数值模拟. 湖泊科学, 2015, 27(4) : 700-710.]

[139] Li HJ, Chen XL, Lu JZ et al. Numerical simulation of suspended sediment concentration in Lake Poyang during flood season considering dredging activities. J Lake Sci, 2016, 28(2) : 421-431. DOI: 10.18307/2016.0223. [李海军, 陈晓玲, 陆建忠等. 考虑采砂影响的鄱阳湖丰水期悬浮泥沙浓度模拟. 湖泊科学, 2016, 28(2) : 421-431.]

[140] Beletsky D, Schwab DJ. Modeling circulation and thermal structure in Lake Michigan: Annual cycle and interannual variability. Journal of Geophysical Research: Oceans, 2001, 106(C9) : 19745-19771. DOI: 10.1029/2000jc000691.

[141] Xue PF, Schwab DJ, Hu S. An investigation of the thermal response to meteorological forcing in a hydrodynamic model of Lake Superior. Journal of Geophysical Research: Oceans, 2015, 120(7) : 5233-5253. DOI: 10.1002/2015jc010740.

[142] Kranenburg W, Tiessen M, Veenstra J et al. 3D-modelling of Lake Kivu: Horizontal and vertical flow and temperature structure under spatially variable atmospheric forcing. Journal of Great Lakes Research, 2020. DOI: 10.1016/j.jglr.2020. 05.012 .

[143] Kuang CP, Gao JB, Liu SG et al. Numerical simulation of 3D wind-driven current in Lake Baikal under typical wind condition. Yangtze River, 2010, 41(3) : 99-101, 106. [匡翠萍, 高健博, 刘曙光等. 贝加尔湖典型风况下三维流场数值 模拟. 人民长江, 2010, 41(3): 99-101, 106.]

[144] Zhao L, Zhang XL, Liu Y et al. Three-dimensional hydrodynamic and water quality model for TMDL development of Lake Fuxian, China. Journal of Environmental Sciences, 2012, 24(8) : 1355-1363. DOI: 10.1016/S1001-0742(11)60967-4.

[145] Carmack EC, Gray CBJ, Pharo CH et al. Importance of lake-river interaction on seasonal patterns in the general circulation of Kamloops Lake, British Columbia. Limnology and Oceanography, 1979, 24(4) : 634-644. DOI: 10.4319/lo.1979.24. 4.0634 .

[146] Bedford BL, Preston EM. Developing the scientific basis for assessing cumulative effects of wetland loss and degradation on landscape functions: Status, perspectives, and prospects. Environmental Management, 1988, 12(5) : 751-771. DOI: 10. 1007/bf01867550.

[147] Sehgal V, Sahay RR, Chatterjee C. Effect of utilization of discrete wavelet components on flood forecasting performance of wavelet based ANFIS models. Water Resources Management, 2014, 28 ( 6 ) : 1733-1749. DOI: 10. 1007/s11269-0140584-4.

[148] Stanford JA, Richard HF. Mitigating the impacts of stream and lake regulation in the Flathead river catchment, Montana, USA: An ecosystem perspective. Aquatic Conservation: Marine and Freshwater Ecosystems, 1992, 2(1) : 35-63. DOI: 10. 
1002/aqc. 3270020104 .

[149] Ou CM, Li JB, Zhou YQ et al. Evolution characters of water exchange abilities between Dongting Lake and Yangtze River. Journal of Geographical Sciences, 2014, 24(4) : 731-745. DOI: 10.1007/s11442-014-1116-0.

[150] Benson LV, Paillet FL. The use of total lake-surface area as an indicator of climatic change: Examples from the Lahontan basin. Quaternary Research, 1989, 32(3) : 262-275. DOI: 10.1016/0033-5894(89)90093-8.

[151] Smith LC. Disappearing arctic lakes. Science, 2005, 308(5727) : 1429. DOI: 10.1126/science.1108142.

[152] Liu YB, Zhang Q, Liu J et al eds. Climate hydrologic and enviromental change in Poyang Lake Basin. Beijing: Science Press, 2012. [刘元波, 张奇, 刘健等. 鄱阳湖流域气候水文过程及水环境效应. 北京: 科学出版社, 2012.]

[153] Birkett CM. Synergistic remote sensing of Lake Chad: Variability of basin inundation. Remote Sensing of Environment, 2000, 72(2), 218-236. DOI: 10.1016/s0034-4257(99)00105-4.

[154] Güntner A. Continental water storage variations from GRACE time-variable gravity data. Heidelberg: Springer Berlin Heidelberg, 2010: 369-375. DOI: 10.1007/978-3-642-10228-8_31

[155] Arsen A, Crétaux JF, Abarca DRR. Use of SARAL/AltiKa over mountainous lakes, intercomparison with Envisat Mission. Marine Geodesy, 2015, 38(sup1) : 534-548. DOI: 10.1080/01490419.2014.1002590.

[156] Hallberg GR, Hoyer BE, Rango A. Application of ERTS-1 imagery to flood inundation mapping. Journal of the American Water Resources Association, 1973, 10: 745-753.

[157] Smith LC. Satellite remote sensing of river inundation area, stage, and discharge: A review. Hydrological Processes, 1997, $11(10): 1427-1439$.

[158] Liu YB, Wu GP, Ke CQ eds. Hydrologic remote sensing. Beijing: Science Press, 2016. [刘元波, 吴桂平, 柯长青. 水 文遥感. 北京: 科学出版社, 2016.]

[159] Choudhury BJ. Monitoring global land surface using Nimbus-737 GHz data theory and examples. International Journal of Remote Sensing, 1989, 10(10) : 1579-1605. DOI: 10.1080/01431168908903993.

[160] Temimi M, Leconte R, Brissette F et al. Flood and soil wetness monitoring over the Mackenzie River Basin using AMSR-E 37GHz brightness temperature. Journal of Hydrology, 2007, 333 (2/3/4): 317-328. DOI: 10. 1016/j. jhydrol. 2006. 09.002 .

[161] Karvonen J, Simila M, Makynen MJIG. Open water detection from Baltic Sea ice radarsat-1 SAR imagery. IEEE Geoscience and Remote Sensing Letters, 2005, 2(3) : 275-279. DOI: 10.1109/lgrs.2005.847930.

[162] Prigent C, Matthews E, Aires F et al. Remote sensing of global wetland dynamics with multiple satellite data sets. Geophysical Research Letters, 2001, 28(24) : 4631-4634. DOI: 10.1029/2001gl013263.

[163] Wu YH, Zhang X, Zheng HX et al. Investigating changes in lake systems in the south-central Tibetan Plateau with multisource remote sensing. Journal of Geographical Sciences, 2017, 27(3) : 337-347. DOI: 10.1007/s11442-017-1380-x.

[164] Prigent C, Papa F, Aires F et al. Global inundation dynamics inferred from multiple satellite observations, 1993-2000. Journal of Geophysical Research: Atmospheres, 2007, 112(D12) : D12107. DOI: 10.1029/2006jd007847.

[165] Crétaux JFO, Birkett C. Lake studies from satellite radar altimetry. Comptes Rendus Geoscience, 2006, 338 (14/15): 1098-1112. DOI: $10.1016 /$ j.crte.2006.08.002.

[166] McFeeters SK. The use of the Normalized Difference Water Index ( NDWI) in the delineation of open water features. International Journal of Remote Sensing, 1996, 17(7) : 1425-1432. DOI: 10.1080/01431169608948714.

[167] Xu HQ. A study on information extraction of water body with the modified Normalized Difference Water Index (MNDWI). Journal of Remote Sensing, 2005, 9(5):589-595. [徐涵秋. 利用改进的归一化差异水体指数( MNDWI) 提取水体信 息的研究. 遥感学报, 2005, 9(5): 589-595.]

[168] Imhoff ML, Vermillion CH, Story MH et al. Monsoon flood boundary delineation and damage assessment using space borne imaging radar and Landsat data. Photogrammetric Engineering and Remote Sensing 1987, 53(4) : 405-413.

[169] Jain SK, Singh RD, Jain MK et al. Delineation of flood-prone areas using remote sensing techniques. Water Resources Management, 2005, 19(4) : 333-347. DOI: 10.1007/s11269-005-3281-5.

[170] Song P, Liu YB, Liu YC. Advances in satellite retrieval of terrestrial surface water parameters. Advances in Earth Science. 2011, 26(7) : 731-740. [ 宋平, 刘元波, 刘燕春. 陆地水体参数的卫星遥感反演研究进展. 地球科学进展, 2011, 26(7) : 731-740.]

[171] Shen GZ, Liao JJ. An object oriented methodology for automatic analysis of inundate extent using multi-polarized SAR im- 
age. Remotesensing Technology and Application, 2007, 22(1):79-82. [沈国状, 廖静娟. 面向对象技术用于多极化 SAR 图像地表淹没程度自动探测分析. 遥感技术与应用, 2007, 22(1) : 79-82.]

[172] Alsdorf DE, Rodríguez E, Lettenmaier DP. Measuring surface water from space. Reviews of Geophysics, 2007, 45 (2) : RG2002. DOI: $10.1029 / 2006 \mathrm{rg} 000197$.

[173] Schumann GJP, Moller DK. Microwave remote sensing of flood inundation. Physics and Chemistry of the Earth, $2015, \mathbf{8 3}$ : 84-95. DOI: 10.1016/j.pce.2015.05.002.

[174] Frappart F, Seyler F, Martinez JM et al. Floodplain water storage in the Negro River basin estimated from microwave remote sensing of inundation area and water levels. Remote Sensing of Environment, 2005, 99(4) : 387-399. DOI: 10.1016/ j.rse.2005.08.016

[175] Li JC, Chu YH, Jiang WP et al. Monitoring level fluctuation of lakes in Yangtze River basin by altimetry. Geomatics and Information Science of Wuhan University, 2007, 32(2) : 144-147. [李建成, 褚永海, 姜卫平等. 利用卫星测高资料监 测长江中下游湖泊水位变化. 武汉大学学报, 2007, 32(2): 144-147.]

[176] Biancamaria S, Frappart F, Leleu AS et al. Satellite radar altimetry water elevations performance over a $200 \mathrm{~m}$ wide river: Evaluation over the Garonne River. Advances in Space Research, 2017, 59(1): 128-146. DOI: 10.1016/j.asr. 2016. 10.008 .

[177] Deng Y, Jiang WG, Tang ZH et al. Long-term changes of open-surface water bodies in the Yangtze River basin based on the Google Earth engine cloud platform. Remote Sensing, 2019, 11(19) : 2213. DOI: 10.3390/rs11192213.

[178] Xiong JG, Wang LT, Wang SX et al. Microwave water extraction supported by multi-spectral images. Journal of China Institute of Water Resources and Hydropower Research, 2012, 10(1): 23-28, 35. [熊金国, 王丽涛, 王世新等. 基于多光 谱影像辅助的微波遥感水体提取方法研究. 中国水利水电科学研究院学报, 2012, 10(1) : 23-28, 35.]

[179] Zhang Y, Chen CC, Wu GP et al. Effects of spatial scale on water surface delineation with satellite images. J Lake Sci, 2015, 27 (2) : 335-342. DOI: 10.18307/2015.0219. [张毅, 陈成忠, 吴桂平等. 遥感影像空间分辨率变化对湖泊水 体提取精度的影响. 湖泊科学, 2015, 27(2) : 335-342.]

[180] Crétaux JF, Abarca-del-Río R, Bergé-Nguyen M et al. Lake volume monitoring from space. Surveys in Geophysics, 2016, 37(2) : 269-305. DOI: 10.1007/s10712-016-9362-6.

[181] Liao JJ, Shen GZ, Li YK. Lake variations in response to climate change in the Tibetan Plateau in the past 40 years. International Journal of Digital Earth, 2013, 6(6) : 534-549. DOI: 10.1080/17538947.2012.656290.

[182] Shen XY, Anagnostou EN, Allen GH et al. Near-real-time non-obstructed flood inundation mapping using synthetic aperture radar. Remote Sensing of Environment, 2019, 221 : 302-315. DOI: 10.1016/j.rse.2018.11.008.

[183] Alsdorf DE, Lettenmaier DP. Tracking fresh water from space. Science, 2003, 301(5639) : 1491-1494. DOI: 10.1126/ science. 1089802.

[184] Li F, Hong WZ. Assessment of water storage change in China's lakes and reservoirs over the last three decades. Remote Sensing, 2019, 11(12) : 1467. DOI: 10.3390/rs11121467.

[185] Wang Y, Ma J, Xiao X et al. Long-term dynamic of Poyang Lake surface water: A mapping work based on the Google Earth Engine cloud platform. Remote Sensing, 2019, 11(3) : 313. DOI: 10.3390/rs11030313.

[186] Wu G, Liu Y. Combining multispectral imagery with in situ topographic data reveals complex water level variation in China's largest freshwater lake. Remote Sensing, 2015, 7: 13466-13484.

[187] Birkett CM. The contribution of TOPEX/POSEIDON to the global monitoring of climatically sensitive lakes. Journal of Geophysical Research: Oceans, 1995, 100(C12) : 25179. DOI: 10.1029/95jc02125.

[188] Feng L, Hu CM, Chen XL et al. Assessment of inundation changes of Poyang Lake using MODIS observations between 2000 and 2010. Remote Sensing of Environment, 2012, 121: 80-92. DOI: 10.1016/j.rse.2012.01.014.

[189] Lu SL, Xiao GH, Jia L et al. Extraction of the spatial-temporal lake water surface dataset in the Tibetan Plateau over the past 10 years. Remote Sensing for Land \& Resources, 2016, 28(3) : 181-187. [卢善龙, 肖高怀, 贾立等. 2000-2012 年 青藏高原湖泊水面时空过程数据集遥感提取. 国土资源遥感, 2016, 28(3): 181-187.]

[190] Wu GP, Liu YB. Capturing variations in inundation with satellite remote sensing in a morphologically complex, large lake. Journal of Hydrology, 2015, 523: 14-23. DOI: 10.1016/j.jhydrol.2015.01.048.

[191] Brivio PA, Colombo R, Maggi M et al. Integration of remote sensing data and GIS for accurate mapping of flooded areas. International Journal of Remote Sensing, 2002, 23(3) : 429-441. DOI: 10.1080/01431160010014729. 
[192] Bastawesy MA, Khalaf FI, Arafat SM. The use of remote sensing and GIS for the estimation of water loss from Tushka lakes, southwestern desert, Egypt. Journal of African Earth Sciences, 2008, 52(3) : 73-80. DOI: 10.1016/j. jafrearsci. 2008.03.006.

[193] Liu YB, Wu GP, Zhao XS. Recent declines in China's largest freshwater lake: Trend or regime shift? Environmental Research Letters, 2013, 8(1) : 014010. DOI: 10.1088/1748-9326/8/1/014010.

[194] Wu GP, Liu YB. Satellite-based detection of water surface variation in China's largest freshwater lake in response to hydroclimatic drought. International Journal of Remote Sensing, 2014, 35(11/12) : 4544-4558. DOI: 10. 1080/01431161. 2014.916444.

[195] Wang JD, Sheng YW, Gleason CJ et al. Downstream Yangtze River levels impacted by Three Gorges Dam. Environmental Research Letters, 2013, 8(4) : 044012. DOI: 10.1088/1748-9326/8/4/044012.

[196] Cai XB, Feng L, Hou XJ et al. Remote sensing of the water storage dynamics of large lakes and reservoirs in the Yangtze River Basin from 2000 to 2014. Scientific Reports, 2016, 6: 36405. DOI: 10.1038/srep36405.

[197] Hou XJ, Feng L, Duan HT et al. Fifteen-year monitoring of the turbidity dynamics in large lakes and reservoirs in the middle and lower basin of the Yangtze River, China. Remote Sensing of Environment, 2017, 190: 107-121. DOI: 10.1016/j. rse.2016.12.006.

[198] Li P, Li H, Chen F et al. Monitoring long-term lake level variations in middle and lower Yangtze Basin over 2002-2017 through integration of multiple satellite altimetry datasets. Remote Sensing, 2020, 12 ( 9): 1448. DOI: 10. 3390/rs12091448.

[199] Zhu LP, Peng P, Zhang GQ et al. The role of Tibetan Plateau lakes in surface water cycle under global changes. J Lake $S c i, 2020,32$ (3) : 597-608. DOI: 10.18307/2020.0301. [ 朱立平, 彭萍, 张国庆等. 全球变化下青藏高原湖泊在地 表水循环中的作用. 湖泊科学, 2020, 32(3): 597-608.]

[200] Zhang GQ, Yao TD, Chen WF et al. Regional differences of lake evolution across China during 1960s-2015 and its natural and anthropogenic causes. Remote Sensing of Environment, 2019, 221: 386-404. DOI: 10.1016/j.rse.2018.11.038.

[201] Yi Y, Lee H, Ibaraki M et al. Louisiana Wetland monitoring using TOPEX/POSEIDON altimetry. Remote Sensing of Environment, 2009, 32(3): 284-302.

[202] Wu HB, Guo ZM, Mao RJ. Monitoring lake water level changes in the middle and lower Yangtze River Basin based on ICESat-GLAS altimetry data. Resources Science, 2012, 34(12) : 2289-2298. [ 吴红波, 郭忠明, 毛瑞娟. ICESat-GLAS 测 高数据在长江中下游湖泊水位变化监测中的应用. 资源科学, 2012, 34(12): 2289-2298.]

[203] Horritt M, Mason D, Cobby D et al. Waterline mapping in flooded vegetation from airborne SAR imagery. Remote Sensing of Environment, 2003, 85(3) : 271-281. DOI: 10.1016/s0034-4257( 03) 00006-3.

[204] Pan X, You CS, Liu YB et al. Evaluation of satellite-retrieved evapotranspiration based on a nonparametric approach over an arid region. International Journal of Remote Sensing, 2020, 41(19) : 7605-7623.

[205] Zhao XS, Liu YB, Wu GP. A remote-sensing-based study on evapotranspiration and the environmental factors over the Lake Poyang region. J Lake Sci, 2013, 25(3) : 428-436. DOI: 10.18307/2013.0318. [赵晓松, 刘元波, 吴桂平. 基于 遥感的鄱阳湖湖区蒸散特征及环境要素影响. 湖泊科学, 2013, 25(3) : 428-436.]

[206] Thiery W, Davin EL, Panitz HJ et al. The impact of the African great lakes on the regional climate. Journal of Climate, 2015, 28(10) : 4061-4085. DOI: 10.1175/jcli-d-14-00565.1.

[207] Liu YB, Wu GP, Zhao XS et al. Remote sensing for watershed hydrology: Issues and challenges. Advances in Earth Science, 2020, 35(5): 488-496. [刘元波, 吴桂平, 赵晓松等. 流域水文遥感的科学问题与挑战. 地球科学进展, $2020,35(5): 488-496$.

[208] Haddeland I, Heinke J, Biemans H et al. Global water resources affected by human interventions and climate change. Proceedings of the National Academy of Sciences of the United States of America, 2014, 111(9) : 3251-3256. DOI: 10.1073/ pnas. 1222475110 .

[209] Zhang D, Zhang Q, Qiu JM et al. Intensification of hydrological drought due to human activity in the middle reaches of the Yangtze River, China. Science of the Total Environment, 2018, 637/638: 1432-1442. DOI: 10.1016/j. scitotenv.2018. 05.121 . 